\title{
Robert F. Kennedy and the Attorney General's Referral Authority: A Blueprint for the Biden Administration
}

Patrick J. Glen

Georgetown University Law Center, pjg32@georgetown.edu

This paper can be downloaded free of charge from:

https://scholarship.law.georgetown.edu/facpub/2331

https://ssrn.com/abstract=3742764

Hofstra Law Review (forthcoming, 2021).

This open-access article is brought to you by the Georgetown Law Library. Posted with permission of the author. Follow this and additional works at: https://scholarship.law.georgetown.edu/facpub

Part of the Immigration Law Commons, and the Law and Politics Commons 


\title{
ROBERT F. KENNEDY AND THE ATTORNEY GENERAL'S REFERRAL AUTHORITY: A BLUEPRINT FOR THE BIDEN ADMINISTRATION
}

\begin{abstract}
For nearly four years, the Trump Administration's use of the Attorney General's referral authority has been criticized by the legal left on both substantive and procedural grounds. With the advent of the Biden Administration, however, use of the authority for liberal ends deserves serious consideration. To conclude otherwise would be throwing the baby out with the bath water. This article argues that the referral authority can be used for liberal constructions of the immigration laws, and that the perfect model for the incoming administration is former Attorney General Robert Kennedy and his use of the authority for just such ends. Rather than continue recent Democrat Administrations' failure to utilize the authority to its full potential, the Biden Administration should look to Kennedy for inspiration, and implement an aggressive use of the referral authority as part of its immigration agenda.
\end{abstract}

\section{INTRODUCTION}

Executive authority over immigration law, whether in the form of executive orders, rulemaking, or internal policy-making memoranda, has been a consistent target of the legal and political left since nearly the moment President Trump was sworn into office in January 2017. With a Democrat administration now set to wield that authority, however, commentators have already begun to set an expansive agenda for the Biden Administration's immigration policy. Some of this work may be reactive, rolling back Trump-era regulations or ensuring that proposed rules are never finalized. Some will likely constitute a continuation of Obama Administration priorities, including revitalizing the Deferred Action for Childhood Arrivals policy, ${ }^{1}$ possibly reinstituting the Deferred Action for Parental Americans program, ${ }^{2}$ and promulgating comprehensive guidance on the use of prosecutorial discretion by the enforcement authorities. ${ }^{3}$ And, of course, the Biden Administration will seek to set its own mark on immigration law and policy as well, using the traditional tools of the Executive Branch over a potentially wide-ranging pool of immigration-related issues.

In advancing this agenda, however, commentators mostly leave out any mention of one of the most potent tools the Executive Branch may wield in advancing its immigration policy agenda:

\footnotetext{
${ }^{1}$ See Memorandum from Janet Napolitano, Sec'y, U.S. Dep't of Homeland Sec., to David V. Aguilar, Acting Comm'r, U.S. Customs \& Border Prot., et al. (June 15, 2012), http://www.dhs.gov/xlibrary/assets/s1-exercising-prosecutorialdiscretion-individuals-who-came-to-us-as-children.pdf.

${ }^{2}$ See Memorandum from Jeh Charles Johnson, Sec'y, U.S. Dep't of Homeland Sec., to Leon Rodriguez, Dir., U.S. Citizenship \& Immigration Servs., et al. (Nov. 20, 2014), http://www.dhs.gov/sites/default/files/publications/14_1120_memo_deferred_action.pdf.

${ }^{3}$ See Memorandum from John Morton, Dir., U.S. Immigration \& Customs Enf't, to all field office directors, all special agents in charge, and all chief counsel (June 17, 2011), http://www.ice.gov/doclib/securecommunities/pdf/procedutorial-discretion-memo.pdf.
} 
the Attorney General's referral authority. ${ }^{4}$ The Attorney General's referral authority rests with a regulatory provision that allows the Attorney General to adjudicate cases in removal proceedings, thereby establishing a uniform interpretation of the law to guide Executive Branch actors in discharging its immigration-related functions. ${ }^{5}$ Trump Administration Attorneys General used this authority to resolve questions on a broad array of procedural and substantive issues. Procedurally, for instance, decisions were issued limiting the ability of the Board of Immigration Appeals and immigration judges to administratively close cases, grant successive continuances, and assume certain aspects of an applicant's eligibility for relief. ${ }^{6}$ Substantively, these decisions established frameworks for considering when private harm may give rise to asylum eligibility, ${ }^{7}$ what an applicant must demonstrate to establish a cognizable "particular social group," ${ }^{8}$ when a criminal offense or conviction will constitute a bar to eligibility for relief or protection, ${ }^{9}$ and various other issues relating to bond proceedings and how or under what circumstances applicants can carry their burden of establishing eligibility for relief and protection under the Immigration and Nationality Act. ${ }^{10}$

In this recourse to the referral authority, the Trump Administration was taking a page from the work of the George W. Bush Administration, whose three Attorneys General utilized the authority over eight years to issue 16 decisions with broad and continuing effect on the application of the immigration laws. ${ }^{11}$ But these administrations were clear outliers in the modern history of the referral authority. Throughout the twelve years of the Reagan and first Bush Administrations,

\footnotetext{
${ }^{4}$ See generally Alberto R. Gonzales \& Patrick Glen, Advancing Executive Branch Immigration Policy Through the Attorney General's Review Authority, 101 IowA L. REV. 841 (2016).

${ }_{6}^{5}$ See 8 C.F.R. $\S 1003.1(\mathrm{~h})$.

${ }^{6}$ See Matter of Castro-Tum, 27 I. \& N. Dec. 271 (A.G. 2018) (holding that the Board of Immigration Appeals and immigration judges do not have general authority to administratively close removal proceedings); Matter of L-A-BR, et. Al., 27 I. \& N. Dec. 405 (A.G. 2018) (clarifying the "for good cause shown" standard for granting a continuance of removal proceedings); Matter of S-O-G- \& F-D-B-, 27 I. \& N. Dec. 462 (A.G. 2018) (applying Matter of CastroTum and clarifying the limited circumstances where an immigration judge may terminate or dismissal removal proceedings); Matter of A-C-A-A-, 28 I. \& N. Dec. 84 (A.G. 2020) (Board must independently address all statutory elements relating to a grant of relief, and may not rely on stipulations by the government).

${ }^{7}$ See Matter of A-B-, 27 I. \& N. Dec. 316 (A.G. 2018) (in the context of victims of domestic-violence, applicant must establish inability of government to protect the individual or that the government condoned the persecution). ${ }^{8}$ See Matter of $A-B-, 27$ I. \& N. Dec. 316 (addressing question in the context of proposed social group of "El Salvadoran women who are unable to leave their domestic relationships where they have children in common" with their partners); Matter of L-E-A-, 27 I. \& N. Dec. 581 (A.G. 2019) (similar, in the context of a proposed social group of the nuclear family).

${ }^{9}$ See Matter of Thomas \& Thompson, 27 I. \& N. Dec. 674 (A.G. 2019) (state-court orders modifying a sentence to be given effect only if based on procedural or substantive defects in the underlying proceeding); Matter of Reyes, 28 I. \& N. Dec. 52 (A.G. 2020) (holding that "[i]f all of the means of committing a crime, based on the elements of the statute of conviction, amount to one or more of the offenses listed in section 101(a)(43) of the INA, then an alien who has been convicted of that crime has necessarily been convicted of an aggravated felony").

${ }^{10}$ See Matter of M-S-, 27 I. \& N. Dec. 509 (A.G. 2019) (aliens placed in expedited removal proceedings are subject to mandatory detention even if they establish a credible fear and are transferred to removal proceedings); Matter of Castillo-Perez, 27 I. \& N. Dec. 664 (A.G. 2019) (clarifying the "good moral character" standard that must be met to establish eligibility for cancellation of removal, and creating a presumption that two or more convictions for drivingunder-the-influence establishes a lack of such character); Matter of R-A-F-, 27 I. \& N. Dec. 778 (A.G. 2020) (clarifying the elements for when harm constitutes "torture" for purposes of protection under the INA's implementing regulations); Matter of O-F-A-S-, 28 I. \& N. Dec. 35 (A.G. 2020) (addressing proper interpretation of regulations implementing the Convention Against Torture).

${ }^{11}$ See Gonzales \& Glen, supra note 4, at 858; see also id. at 861-94 (noting the variety of contexts in which Attorneys General issued decisions during the Bush Administration).
} 
the authority was used sparingly, while receding still further from the active quiver of policy options in the two most recent Democrat administrations, those of Presidents Clinton and Obama.

This clear disparity in the use of the authority has provided a gloss to criticisms from the left which, while aimed ostensibly at concerns over the authority itself, seem more concerned with the substance of the decisions that are being reached. Addressing these criticisms is outside the scope of this Article for two reasons. First, on their face, these criticisms are ahistorical and fail to understand the primacy of the Attorney General to the statutory design enacted by Congress. Second, the meat of these criticisms has been dealt with fully elsewhere, and nothing in the more recent academic treatment of the referral authority provides occasion for reconsideration.

Rather, this Article seeks to put the lie to the undercurrent in many contemporary accounts of referral that it represents a partisan project and that its use is invariably to the detriment of the alien. Although perhaps more true than false in its modern usage, even recent decisions have at times liberalized interpretations of the immigration laws to the benefit of applicants for relief. ${ }^{12}$ Even in the absence of such use, however, the authority is inherently neutral -it provides a mechanism for the resolution of immigration issues by the Attorney General, but does not cabin how he or she may resolve those issues. In cases where the law is genuinely ambiguous and thus interpretive authority may be exercised, it is up to the Attorney General to decide the proper construction of the statute. Based on an administration's preferences, that may well entail strict application and interpretation of the INA. But it just as easily could entail a liberal construction animated by humane considerations. Although this latter possibility has not been realized in the preceding 40 years, history does provide a good example: the Kennedy Administration, and the decisions issued by Attorney General Robert F. Kennedy.

Between assuming office in the early part of 1961, and departing in September 1964 on his path to the Senate, Kennedy issued eleven immigration decisions as Attorney General. Kennedy's interpretations were always focused on the human dimension of the case, and the need, in light of the stakes to the individual, to provide a liberal construction where the language of the statute was susceptible to such construction. In other words, in circumstances where one of two interpretations was possible, Kennedy erred on the side of providing a benefit or forestalling removal rather than on a stricter-though still plausible and permissible-interpretation. At the same time, this impulse did not permit straying beyond the text Congress enacted to implement a view of immigration law that was not fairly traceable to the statute. Where the language left no doubt as to its application, Kennedy applied it without hesitation, even where it entailed harsh consequences for the alien.

This Article proceeds in four parts. First, Part I provides a brief overview of the history and mechanics of Attorney General referral. Part II then turns to the decisions issued by Attorney General Kennedy in his nearly four years at the head of the Department of Justice. In these decisions, Kennedy was unhesitant to apply strict provisions by their literal terms, where that coincided with the intent of Congress and supplied the only permissible reading of the text. At the same time, in the majority of cases, the statute provided a range of possible permissible interpretations, and Kennedy was similarly unhesitant to adopt the more liberal construction where

${ }^{12}$ See, e.g., Matter of A-T-, 24 I. \& N. Dec. 617 (A.G. 2008) (rejecting the Board's conclusion that female genital mutilation is effectively a one-time persecutory event). 
the language so permitted. These decisions were, then, on the whole informed by a humane approach to the law that prioritized liberal construction over strict construction, where Congress entrusted interpretation to the Executive Branch. Part III advances the narrative to the two most recent Democrat administrations and their use of the referral authority. Unlike Kennedy, no Attorney General in the Clinton or Obama administrations utilized the referral authority as a component of the administration's immigration policy. The decisions issued between 1993-2001 and 2009-2017 were largely non-substantive and had no lasting impact on the understanding or interpretation of the INA. Finally, Part IV argues that the incoming Biden Administration should look to the example set by Attorney General Kennedy. Although Attorney General referral has been an important component of advancing the policy agendas of Republican administrations, nothing about the authority is inherently partisan. The experience of the Kennedy Administration highlights this fact. An administration interested in liberalizing immigration law and policy has a ready tool available to it in referral, and the Biden Administration would be ill-served by following the examples of the Clinton and Obama Administrations in failing to utilize that tool.

\section{THE ATtOrney General's ReFERRAL AUTHORITY: AN OVERVIEW}

"Head of Department" review has been a feature of the immigration bureaucracy for nearly as long as that system has existed. Prior to 1940, it was the Secretary of Labor who authorized final orders in immigration cases, based on recommendations made to the Secretary by intermediate officers, including the predecessor to the Board of Immigration Appeals. ${ }^{13}$ In 1940, as part of a broader reorganization of the federal government occasioned by the commencement of hostilities in Europe, immigration functions were transferred from the Department of Labor to the Department of Justice. ${ }^{14}$ As President Roosevelt wrote in transmitting his plan:

[T]he startling sequence of international events which has occurred since [the submission of Reorganization Plan No. IV] has necessitated a review of the measures required for the Nation's safety. This has revealed a pressing need for the transfer of the immigration and naturalization functions from the Department of Labor to the Department of Justice.... I am convinced ... that under existing conditions the immigration and naturalization activities can best contribute to the national well-being only if they are closely integrated with the activities of the Department of Justice. ${ }^{15}$

It was at this point "that the Board of Immigration Appeals was created by regulation of the Attorney General as a separate entity in the Department of Justice, responsible directly to the Attorney General and completely independent of the [Immigration and Naturalization] Service."16

\footnotetext{
${ }^{13}$ See Maurice A. Roberts, The Board of Immigration Appeals: A Critical Appraisal, 15 SAN DIEGO L. REV. 29, 3334 (1977).

${ }^{14}$ Reorganization Plan No. V of 1940, ch. 231, § 1, 54 Stat. 230; see Patrick J. Glen, Judulang v. Holder and the Future of 212(c) Relief, 27 GEO. IMMIGR. L.J. 1, 7 (2012).

15 Message of the President Regarding Reorganization Plan No. V, May 22, 1940, available at http://www.gpo.gov/fdsys/pkg/USCODE-2010-title5/html/USCODE-2010-title5-app-reorganiz-other-dup4-htm.

${ }^{16}$ Roberts, supra note 13 , at 34.
} 
The Attorney General set the jurisdiction of the Board by regulation, and provided that itunlike the prior Board of Review within the Department of Labor-could make a final adjudication of a case rather than simply recommend a disposition to the INS Commissioner and the Secretary. ${ }^{17}$ As originally constituted, the Board functioned as a non-appellate front-line adjudicator of cases, assisted in this task by recommendations made by INS officials. ${ }^{18}$ Following enactment of the Immigration and Nationality Act of 1952, however, decisions of so-called "special inquiry officers," the functional equivalent of contemporary immigration judges, could constitute final orders, with the Board exercising appellate jurisdiction over these decisions in exclusion and deportation cases. ${ }^{19}$

Despite the long history of the Board, it enjoys no independent statutory existence, ${ }^{20}$ and it has authority to act only to the extent the Attorney General provides it with delegated authority. ${ }^{21}$ It was the Attorney General alone who was statutorily charged, and remains statutorily charged together with the Secretary of the Department of Homeland Security, with the administration and enforcement of immigration law. ${ }^{22}$ The Board is, however, charged with exercising independent judgment in all cases it decides, ${ }^{23}$ and its decisions are considered its own and not that of the Attorney General. ${ }^{24}$ This independence is safe-guarded by the so-called Accardi principle, that the Attorney General may not attempt to influence or dictate the decisions of cases pending before the Board. ${ }^{25}$

Nonetheless, since the Attorney General's delegation of authority to the Board, the regulations have provided a mechanism for the Attorney General to exercise his authority directly rather than through his delegate - the "referral authority." 26 As originally promulgated, the referral regulation provided:

\footnotetext{
${ }^{17}$ See ibid.

${ }^{18}$ See id. at 34-35.

${ }^{19}$ See id. at 35.

${ }^{20}$ See Gonzales \& Glen, supra note 4, at 849-51; see also Harry N. Rosenfield, Necessary Administrative Reforms in the Immigration and Nationality Act of 1952, 27 FORDHAM L. REV. 145, 155 (1958).

${ }^{21}$ See 8 C.F.R. § 1003.1(d)(1) ("The Board shall function as an appellate body charged with the review of those administrative adjudications under the Act that the Attorney General may by regulation assign to it."); 5 Fed. Reg. 2454 (July 1, 1940) ("the Board of Review of the Immigration and Naturalization Service shall have authority to exercise the powers of the Attorney General" in certain delineated circumstances).

${ }^{22}$ See 8 U.S.C. $\S \S 1103(\mathrm{a}),(\mathrm{g})$.

${ }^{23}$ See 8 C.F.R. § 1003.1(d)(1)(ii) ("Subject to these governing standards, Board members shall exercise their independent judgment and discretion in considering and determining the cases coming before the Board, and a panel or Board member to whom a case is assigned my take any action consistent with their authorities under the Act and the regulations as is appropriate and necessary for the disposition of the case.").

${ }^{24}$ See, e.g., Tefel v. Reno, 972 F.Supp. 608, 613 n.1 (S.D. Fla. 1997) ("the decision of the BIA is not factually, nor legally, the decision of the Attorney General.").

${ }^{25}$ See United States ex rel. Accardi v. Shaughnessy, 347 U.S. 260, 266-67 (1954) ("In unequivocal terms the regulations delegate to the Board discretionary authority as broad as the statute confers on the Attorney General; the scope of the Attorney General's discretion became the yardstick of the Board's. And if the word 'discretion' means anything as a statutory or administrative grant of power, it means that the recipient must exercise his authority according to his own understanding and conscience. This applies with equal force to the Board and the Attorney General. In short, as long as the regulations remain operative, the Attorney General denies himself the right to sidestep the Board or dictate its decision in any manner.").

${ }^{26}$ See, e.g., Sanchez-Penunuri v. Longshore, 7 F.Supp. 2d 1136, 1149 (D. Colo. 2013) ("although he rarely uses this power, the Attorney General is the final arbiter of the immigration agency's interpretation of a statute").
} 
In any case in which a dissent has been recorded; in any cases in which the Board shall certify that a question of difficulty is involved; in any case in which the Board orders the suspension of deportation pursuant to the provisions of section 19(c) of the Immigration Act of 1917, as amended, or in any case in which the Attorney General so directs, the Board of Immigration Appeals shall refer the case to the Attorney General for review of the Board's decision. In any case in which the Attorney General shall reverse the decision of the Board, or in any case in which suspension of deportation is ordered pursuant to the provisions of section 19(c) of the Immigration Act of 1917, as amended, the Attorney General will state in writing his conclusions and the reasons for his decision. ${ }^{27}$

The regulation underwent several changes between 1940 and the present, including clarifying who may request referral and eliminating specific grounds justifying referral. ${ }^{28}$ As currently drafted, the regulation provides:

(1) The Board shall refer to the Attorney General for review of its decision all cases that:

(i) The Attorney General directs the Board to refer to him.

(ii) The Chairman or a majority of the Board believes should be referred to the Attorney General for review.

(iii) The Secretary of Homeland Security, or specific officials of the Department of Homeland Security designated by the Secretary with the concurrence of the Attorney General, refers to the Attorney General for review.

(2) In any case the Attorney General decides, the Attorney General's decision shall be stated in writing and shall be transmitted to the Board or Secretary, as appropriate, for transmittal and service as provided in paragraph (f) of this section. ${ }^{29}$

\section{THE IMMIGRATION DECISIONS OF ROBERT F. KENNEDY}

Immigration reform is intimately tied to the Kennedy political legacy. In 1958, thenSenator John F. Kennedy published his short book A Nation of Immigrants, arguing, among other reform proposals, for repealing the national-origin system that prioritized immigration from western Europe while greatly minimizing the opportunity to emigrate from other parts of the world. ${ }^{30}$ As president, Kennedy championed the same reform which, following his assassination, was taken up by Senator Edward Kennedy and the Johnson Administration. ${ }^{31}$ The result was the Immigration Act of 1965, eliminating the national origin system and assigning visa availability on

\footnotetext{
278 C.F.R. $\$ 90.12$ (1940); see Bridges v. Wixon, 326 U.S. 135, 139 n.3 (1945).

${ }^{28}$ See Gonzales \& Glen, supra note 4, at 850-52.

${ }^{29} 8$ C.F.R. $\$ 1003.1(\mathrm{~h})$.

30 John F. Kennedy, A NATiOn Of Immigrants 74-76, 77-83 (2d ed.) Harper \& Row 1964).

31 See generally Edward M. Kennedy, The Immigration Act of 1965, 367 Annals Of THE AM. ACAD. OF POL. \& SOC. SCIENCE 137 (1966).
} 
a more equitable basis. ${ }^{32}$ And even before his presidency, John Kennedy was active in advancing immigration issues in Congress, including "the Displaced Persons Act and the Refugee Relief Act, which he sponsored while in Congress," and a subsequent 1957 bill aimed at bringing "families together, which he led to passage in the Senate." ${ }^{33}$ Senator Edward Kennedy would also go on to be the driving force behind the Refugee Act of 1980, as well as other immigration policy initiatives in his nearly fifty years in the United States Senate. ${ }^{34}$

Within this expansive legacy, it would be easy to lose sight of Robert Kennedy. To be sure, he was involved in the committee hearings on the 1965 Act and played a role in shepherding that bill through the Senate. ${ }^{35}$ And he had earlier provided testimony as Attorney General on immigration issues, expressing "his conviction that there are few areas in our law which more urgently demand reform than our present unfair system of choosing the immigrants we will allow to enter the United States." 36 But his main contribution to the Kennedy immigration legacy lies with his exercise of the Attorney General referral authority in the nearly four years he spent at the helm of the Department of Justice. During that time, he decided eleven cases, significantly more than any Attorney General since and more than even most two-term administrations have managed to issue. His decisions evidence sympathy for the plight of those caught up in the immigration system, and a desire to implement humane interpretations that fairly balance congressional intent with the fundamentally human-dimensions of the cases. This is, of course, not to say he invariably ruled for the immigrant. He did not. But even in cases where the law compelled a rejection of the argument raised by the alien, Kennedy evinced a profound understanding of the stakes of the case and the consequences that would be suffered by the individual, even if the law left no real choice as to the imposition of those consequences.

This Part proceeds by considering the substantive decisions issued by Kennedy as Attorney General, grouped in subparts around a broad issue heading: First, decisions resolving questions presented in the context of family-based immigration; Second, criminal law questions, a nascent topic at that time; Third, cases on citizenship issues and expatriation; and Fourth, cases where an alien's admissibility to the United States was at issue, and there were arguable grounds for finding him inadmissible based on certain misrepresentations. Although not addressed in great detail below, Kennedy also made contributions to how the referral authority was conceived. He noted, for instance, that referral should be used to resolve legal questions of significant importance, not essentially factual disputes over which reasonable minds could and did differ. ${ }^{37}$ And he concluded that although it is usually preferable to wait for a Board decision resolving the legal questions raised, in certain cases the Attorney General could accept referral prior to that resolution where

\footnotetext{
32 See Immigration Act of 1965, Pub. L. No. 89-235, 79 Stat. 911 (1965).

${ }^{33}$ RoBert F. KENNEDY, Introduction, at ix, in KenNEDy, supra note 30; see Displaced Persons Act of 1948, Pub. L. No. 80-774, 62 Stat. 1009 (1948); Refugee Relief Act of 1953, Pub. L. No. 83-203, 67 Stat. 400 (1953).

${ }^{34}$ See Refugee Act of 1980, Pub. L. No. 96-212, 94 Stat. 102 (1980).

${ }^{35}$ See Kennedy, supra note 31, at 141-43 \& n.12.

${ }^{36}$ KENNEDY, Introduction, at $\mathrm{X}$, in KENNEDY, supra note 30.

37 See Matter of R-E-, 9 I. \& N. Dec. 720, ** (BIA 1961, 1962; A.G. 1962) ("The only issue for decision which I find in this case is whether, on its particular record, the majority or the dissenters are correct in their assessment of the facts leading to the conclusion that the alien had satisfied the burden imposed upon him. This is not ordinarily an issue appropriate for reference to me under the pertinent regulations. The record is one upon which reasonable men can differ and have differed. Further consideration of the question has established no general principle would could guide the disposition of other cases, or revealed any clear error on the part of the Board.").
} 
deciding the legal question did not turn on resolving any dispute as the particular facts in the case. ${ }^{38}$ These decisions are an important component of how the referral authority has come to be understood, but fall outside the scope of the instant article. ${ }^{39}$

\section{A. Family-Based Immigration}

The possibilities of a humanitarian-based interpretation of the INA are nowhere more apparent than in Kennedy's opinions dealing with family-based immigration issues. As Attorney General, Kennedy issued three decisions on a range of issues pertaining to whether or in what circumstances an alien was entitled to pursue lawful admission to the United States. In each case, where either of two competing interpretations would have been a reasonable construction of the statutory language, Kennedy opted for the more liberal and permissive approach.

The INA established a category of non-quota immigrants, outside the numerical limitations otherwise applicable to aliens seeking to immigrate, defined as an individual "who is the child or the spouse of a citizen of the United States[.]" 40 The INA in turn defined "child" to mean, inter alia, "an unmarried person under twenty-one years of age who is - ... (E) a child adopted while under the age of fourteen years if the child has thereafter been in the legal custody of, and has resided with, the adopting parent or parents for at least two years[.]"41 If there are two adopting parents, does the residency requirement apply as to both? Attorney General Herbert Brownell initially answered yes, disallowing non-quota status to the child of a United States citizen who had resided more than two years with his adoptive mother, but less than two years with his adoptive father. ${ }^{42}$ Brownell interpreted the definition of "child" "to require that the 2-year legal custody and residence of the adopted child be had with both the adoptive parents, where [two] exist or with one when the family unit consisted of only one adoptive parent."43 The interpretation was justified, according to Brownell, by congressional purpose: "it is restoration of a bona fide family relationship which is the Congressional objective," and that objective would not be served where the family relationship never existed. ${ }^{44}$

Brownell's decision was the subject of significant litigation in the federal courts, with most rejecting his construction of the statute. ${ }^{45}$ Representative of these decisions was the Southern District of New York's opinion in $\mathrm{Ng}$ Fun Yin, holding that non-quota status was required where the adoptive mother, but not the adoptive father, had met the 2-year residency requirement: "I believe the general purpose [of fostering continued bona fide family relationships] can be implemented only by granting plaintiff's adopted son non-quota status. There is no doubt

\footnotetext{
38 See Matter of Picone, 10 I. \& N. Dec. 139, 145 (BIA; 1962, 1962; A.G. 1963) ("Although it is ordinarily the better practice to refer to the Attorney General only cases in which the Board has reached a final decision on the merits, I am accepting this case because the legal question involved is a recurring one and its resolution does not hinge on the particular facts shown by the record.").

39 See, e.g., Gonzales \& Glen, supra note 4, at 860 (placing these decisions in the context of how the scope of the Attorney General's referral authority has evolved and come to be understood in practice).

408 U.S.C. $\$ 1101(\mathrm{a})(27)(\mathrm{A})(1957)$.

418 U.S.C. $\$ 1101(\mathrm{~b})(1)(\mathrm{E})$ (1957) (emphasis added).

${ }^{42}$ See Matter of C-F-L-, 8 I. \& N. Dec. 151, 165-66 (A.G. 1959).

${ }^{43} I d$. at 166.

${ }^{44}$ Ibid.; see ibid. ("These provisions are remedial in nature and were enacted by Congress to reunite an adopted child with his parents where a bona fide family relationship has been interrupted.").

${ }^{45}$ See Matter of Y-K-W-, 9 I. \& N. Dec. 176, 177-79 (A.G. 1961).
} 
whatsoever that plaintiff and his wife have ... had a bona fide family relationship. There is also no doubt that plaintiff's wife and plaintiff's adopted child have had ... a bona fide family relationship. The only way in which these two relationships can be maintained is to allow all three of the individuals involved to maintain a single residence." 46

Reviewing the issue in a subsequent case, Kennedy focused on the legislative history that, although sparse, "provide[d] support for a liberal interpretation of the statutory language." 47 Kennedy did agree with aspects of Brownell's construction, concurring that the statute was meant to serve a remedial purpose and "to prevent hardship in cases where the child is chargeable to a heavily oversubscribed quota and would not otherwise be able to accompany his adoptive parents." $"$ In effectuating that purpose, however, it was the interpretation of $N g$ Fun Yin that should control, not Brownell's opinion in Matter of C-F-L-. ${ }^{49}$ "[T] that legal custody and residence be had with 'the adopting parent or parents' is satisfied if had with only one of the adopting parents for the requisite two years." 50 Moreover, Kennedy opined that adequate safeguards remained in place to prevent fraud or abuse of the provision, as adjudicators could look "at the surrounding circumstances of the adoption and mak[e] a determination on the facts that, assuming the statutory qualifications to be met, the legislative purposes would be served in a particular case." 51 In other words, in cases where there is evidence of fraud in attempting to procure the non-quota status for a child, the government would be entitled to rely on the fraud and deny status. ${ }^{52}$ That not being the case as regarded Y-K-W-, the Attorney General granted nonquota status.

In Matter of $K-W-S$-, Kennedy was confronted with a question of whether an alien was entitled to fourth-preference status as the brother of a United States citizen. ${ }^{53}$ The statute provided such preference-status to siblings, whether by full or half-blood, but had different rules for qualifying siblings under the half-blood rubric depending on who the common parent was: " $[\mathrm{w}]$ here the common parent is the mother, the offspring are regarded as half-brother and halfsister, whether or not legitimate.... [W] here the common parent is the father but different mothers are involved, the illegitimate child is not eligible for fourth preference as a half-brother or sister" automatically. ${ }^{54}$ Rather, in such circumstances, "it becomes necessary for the petition to establish that the beneficiary is a legitimate half-brother." 55 The petitioner sought fourth-preference status for her half-brother, who was the offspring of the same father, but a different mother-the concubine of the father. ${ }^{56}$ Reviewing relevant Chinese law, the Board determined that children of

${ }^{46} \mathrm{Ng}$ Fun Yin v. Esperdy, 187 F.Supp. 51, 53-54 (S.D.N.Y. 1960).

${ }^{47}$ Matter of $Y-K-W-, 9$ I. \& N. Dec. at 179.

${ }^{48}$ Ibid. (quoting H. Rept. No. 1057, 85th Cong., 1st Sess., at 4).

${ }^{49}$ Matter of $Y-K-W-, 9$ I. \& N. Dec. at 179-80.

${ }^{50} I d$. at 180.

${ }^{51}$ Ibid.

${ }^{52}$ See ibid. ("there has been no challenge to the bona fides of the family relationships involved. The validity of the marriage of the parents and the adoption of the child are unquestioned. Nor is any question raised as to whether the child was in the legal custody of and resided with the wife for the required period. There is, therefore, no evidence of fraud. The remedial and humanitarian purpose of section 101(b)(1)(E) would not be applicable in any future case in which such evidence is present.").

53 9 I. \& N. Dec. 396 (BIA 1958, 1961; A.G. 1961).

${ }^{54} I d$. at 397.

${ }^{55} \mathrm{Ibid}$. (emphasis added).

${ }^{56} I d$. at 396-97. 
concubines are not considered to be illegitimate, and can be "legitimate" based on acknowledged by the father of the child. ${ }^{57}$ Accordingly, the Board "approve[d] the visa petition with the admonition that the consul, in view of the absence of documents, [could] require additional evidence before he is satisfied as to relationship and identity." 58 The Board held to this view in a subsequent decision, despite motions by the INS and the Department of State, arguing that its holding was contrary to public policy. ${ }^{59}$ In rejecting the government's submissions, the Board again relied on the law of the domicile and residence of the father to gauge legitimacy, noting that "a child ... that is legitimate in the place of his birth is legitimate everywhere." 60 The child being considered legitimate in China, the Board held to its prior interpretation, but referred the case to the Attorney General based on the concerns raised by the Department of State. ${ }^{61}$

On review, Kennedy accepted the fact of Chinese law and that the beneficiary was a legitimate child under that law. ${ }^{62}$ Turning to the INA, Kennedy wrote that the statutory definition of "child" and the preference categories generally were enacted "to implement "the wellestablished policy of maintaining the family unit wherever possible." 63 Echoing the rationale from his earlier decision in Matter of $Y-K-W$-, Kennedy reasoned that "[s]ympathetic and humane considerations dictate an interpretation which would not separate a child, whether legitimate or illegitimate, from its alien parent," a rule that would apply equally to other familial relationships, including "the case of a half-brother or half-sister, born out of wedlock, who desires to confer preferential immigrant status under" the INA. ${ }^{64}$ Extending preference status in this circumstance may not have been compelled by the statute, but "it would appear to be a desirable result, based upon legal and equitable considerations, to adopt a liberal construction. No harm could possibly result from such a construction, and the consequences would fulfill the humane considerations involved in keeping intact the family unit."65 The Attorney General also rejected the public policy considerations proffered by the Department of State for declining to recognize such children. First, on its own terms, Kennedy concluded that the INA already provided sufficient bases to deny benefits to individuals who were themselves engaged in polygamy. ${ }^{66}$ Second, regardless of policy concerns over relationships with multiple partners or spouses, there was no public policy reason for denying the offspring of those relationships appropriate status under the INA. This was especially so, according to Kennedy, where "Congress deems it more in accordance with humanitarian principles to try to keep together those offspring of a common parent who have lived together as a family unit in accordance with the established laws and institutions of their place of residence, regardless of whether or not those laws are in conformity with our own social and family institutions." 67

\footnotetext{
${ }^{57}$ Id. at $398-400$.

58 Id. at 400.

${ }^{59}$ See id. at 400-07; see also id at 401 (the Departments have "asked that the decision be reconsidered on the grounds that it offends public policy and is contrary to long-standing rulings of the Department").

${ }^{60} \mathrm{Id}$. at 404.

${ }^{6161}$ See id. at 407.

${ }^{62} \mathrm{Id}$. at 408 ("These findings as to Chinese law and as to the facts relating to the relationship between the petitioner, the beneficiary and their parents, are not contested.").

${ }^{63} \mathrm{Id}$. at 409.

${ }^{64}$ Ibid.

${ }^{65}$ Ibid.

${ }^{66}$ See id. at 410 (citing 8 U.S.C. $\$ 1182(a)(11)(1957)$ ).

${ }^{67}$ Matter of $K-W-S-, 9$ I. \& N. Dec. at 410; see id. at 409-10 ("I cannot attribute to a Congress thus solicitious for keeping together those persons who have in fact lived together as a family an intention to deny fourth preference status
} 
A similarly perplexing issue was subsequently presented in the context of third-preference category visas, which were available to "the spouses and children of aliens lawfully admitted for permanent residence." $" 68$ A lawful permanent resident filed a visa petition on behalf of his son, which was approved on January 31, 1958. ${ }^{69}$ That category was oversubscribed, however, so no visa was available to him as of that date. ${ }^{70}$ Although placed on the waiting list, he aged out of "child" status on June 2, 1959, when he obtained the age of majority. ${ }^{71}$ He was thus automatically removed from the waiting list by operation of law. ${ }^{72}$

In September 1959, Congress acted to enlarge the third-preference category to include "unmarried sons or daughters" of lawful permanent residents, i.e., children over the age of $21 .{ }^{73}$ That Act, applicable prospectively only in terms of visa petitions, nonetheless contained two exceptions to extend non-quota immigrant status to certain eligible individuals with visa petitions approved prior to January 1, 1959. ${ }^{74}$ Each exception contained the same proviso, however: it applied only if "upon his application for an immigrant visa, and for his admission into the United States, the alien is found to have retained his relationship to the petitioner, and status, as established in the approved petition."75 The focal point was "status" and what "status" must have been retained. The INS argued that the relevant status was marital status, not age, and thus had approved the petition for non-quota status. ${ }^{76}$ The Department of Statute, however, believed that the relevant status was both age and marital status, which meant that the beneficiary did not qualify for either exception. ${ }^{77}$ The Board, on review, held that status referred to consanguinity only, and approved the petition. ${ }^{78}$

The Attorney General disagreed with the reasoning, but not with the bottom-line. He concluded that "[t]he purpose of sections 4 and 6 of the 1959 Act was to reunite families and to relieve a backlog resulting from oversubscribed quotas which cause unusually long delays in the issuance of immigration quota visas for aliens already accorded preference status."79 In light of the intent behind the Act, the most logical meaning of "status" related to the "preference quota status" to which both sections explicitly referred. ${ }^{80}$ The contrary interpretations were not compelling. The Board's construction would make the term "status" superfluous, since both sections already required retention of the qualifying relationship. ${ }^{81}$ In contrast, the Department of State's interpretation placed too great an emphasis on the facts that contribute to the statute,

to children who were regarded as legitimate brothers and sisters under the law of their own and their parents' residence.").

68 8 U.S.C. $\$ 1153(\mathrm{a})(3)$ (1957).

${ }^{69}$ Matter of Y-J-G-, 9 I. \& N. Dec. 471, 472 (A.G. 1961).

${ }^{70}$ Ibid.

${ }^{71}$ Ibid.

${ }^{72}$ Ibid. (citing 8 C.F.R. $§ 206.1(b)(5)$ (1957)).

${ }^{73}$ Matter of $Y-J-G-, 9$ I. \& N. Dec. at 472.

${ }^{74} I d$. at 472-73 (citing Act of Sept. 22, 1959, §§ 4, 6).

${ }^{75}$ Matter of $Y-J-G-, 9$ I. \& N. Dec. at 473 (emphasis added).

${ }^{76}$ Ibid.

${ }^{77}$ Id. at 473-74.

${ }^{78} \mathrm{Id}$. at 474.

${ }^{79}$ Ibid. (citing 105 Cong. Rec. 12,716, 18,996).

${ }^{80}$ Matter of Y-J-G-, 9 I. \& N. Dec. at 474-75.

${ }^{81} \mathrm{Id}$. at 475 . 
including marital status and age, than the status itself. ${ }^{82}$ Although the beneficiary's status did change between aging out of child status in June 1959 and the expansion of the preference category in September 1959, the relevant status-qualifier for third-preference category status-was reinstated by the 1959 Act, which "restored [the] previous status." 83 In other words, the status of the beneficiary was at all times that of an individual eligible for third-preference category status, and it was that status that was "retained" via reinstatement by the 1959 Act. $^{84}$

In each of these cases, there were at least two reasonable ways to resolve the issue. In Matter of $Y-K-W$-, it would have been reasonable to read the statute as requiring an adopted child to be in the legal custody and reside with both parents for the required two-year period, an interpretation arguably supported by the intent of Congress in providing for reunification of separated family units. Public policy could well have supported the stricter interpretation offered by the Department of State in Matter of $K-W-S$-, whereby the children of concubines would be outside the scope of "relatives" for purposes of allocating visas under the preference categories. Likewise, the narrower interpretation advanced by the Department of State in Matter of Y-J-Gwas not on its face erroneous, and the generous benefit of non-quota status could well have been meant only for those then eligible for classification within the appropriate preference category in line with Congress's intent to ease oversubscribed waiting lists. In other words, nothing in these cases compelled the decision ultimately issued by Attorney General Kennedy.

Instead, Kennedy consciously adopted a liberal construction of the provisions in line with humanitarian principles. In both Matter of $Y-K-W$ - and Matter of $K-W-S$ - that rested on the principle of family unity - that families should be able to live together in the United States, and that any interpretation ending with that result should be preferred if otherwise reasonable under the statutory language. Family unity also played a role in Matter of $Y-J-G-$, but a strong current of equity also pervades the opinion. The beneficiary's visa petition had been approved, and the only reason he had not been able to immigrate was because of the oversubscription of that preference category. His aging-out was in no real sense his own fault, and it was that sequence of events that suddenly placed him on the outside of the system looking in. Congress acted to address that inequity by enacting the exceptions in the 1959 Act to provide non-quota status to individuals with previously approved visa petitions, and reading those provisions broadly to include individuals whose status lapsed prior to enactment of the 1959 Act was in service of that goal. These decisions, as much as any issued by Kennedy, establish the space an Attorney General retains to act for the benefit of the alien. To be sure, not every provision is fairly susceptible to a liberalizing interpretation, but there is no shortage of provisions that are. When confronted with the opportunity in the context of family-related immigration issues, Kennedy never failed to capitalize and advance his humane vision of the law.

\footnotetext{
${ }^{82}$ See id. at 476.

83 Ibid.

${ }^{84}$ Id. at 477; see ibid.("It is enough that, as in this case, eligibility existed at the time the petition was approved and exists at the time of application for an immigrant visa and for admission into the United States.").
} 


\section{B. Criminal Law Questions}

Kennedy resolved only one criminal-law related question during his tenure, involving an issue that has engaged numerous Attorneys General in the preceding 80 years: the immigration consequences of state and federal post-conviction relief schemes. ${ }^{85}$

The INA provided that "any alien ... who at any time after entry is convicted of two crimes involving moral turpitude, not arising out of a single scheme of criminal misconduct, regardless of whether confined therefor and regardless of whether the convictions were in a single trial," is deportable. ${ }^{86}$ The Act also provided that such an alien shall not be deported "if the court sentencing such alien for such crime shall make, at the time of first imposing judgment or passing sentence ... a recommendation to the Attorney General that such alien not be deported..." ${ }^{17}$ An alien was convicted of two offenses, both of which were conceded to be crimes involving moral turpitude. ${ }^{88}$ At his sentencing in March 1959, no judicial recommendation against deportation was made by the judge.$^{89}$ The alien subsequently filed a petition for a writ of coram nobis and motion for a new trial, which was granted by the trial court. ${ }^{90} \mathrm{He}$ was again convicted, but "[a]t this second trial the court recommended against his deportation." 91 The Board, however, refused to give effect to this second proceeding, holding that it was the initial March 1959 entry of judgment that was relevant under Section 1251(b), and that because "the vacation and reentry of judgment was for the sole purpose of petitioning the court to make the statutory recommendation against deportation," it "was not timely and was ineffectual." 92

On referral to the Attorney General, the question was framed as to "whether the recommendation of the court against deportation satisfies the requirement of section [1251(b)] that to be effective it must be made 'at the time of first imposing judgment or passing sentence."'93 The Attorney General noted that Second Circuit precedent had held that the writ of coram nobis would not be effectual for such purposes "where the sole basis for the vacation and reentry of judgment is to repair the omission to make the statutory recommendation against deportation permitted by $\S 1251(\mathrm{~b}) . "$ " ${ }^{4}$ As that court reasoned, "[t]o hold otherwise would be to defeat the plain command of the statute, which strictly, and for good purpose, limits the time within which the extraordinary power vested in the trial court must be exercised." 95 The Attorney General accepted this holding, but concluded that the Board had erred in focusing on the alien's asserted motivation for pursuing the writ, rather than the court's in granting the writ. First, the petition itself requested relief on two grounds unrelated to the judicial-recommendation issue: a lack of counsel and a lack of adequate translation. ${ }^{96}$ Second, it was those two bases that were the focus

\footnotetext{
${ }^{85}$ Matter of P-, 9 I. \& N. Dec. 293 (A.G. 1961); see Gonzales \& Glen, supra note 4, at 868-70 (reviewing the long history of Attorney General decisions on expungement and related issues).

868 U.S.C. § 1251(a)(4) (1957).

878 U.S.C. $\$ 1251$ (b) (1957).

${ }^{88}$ Matter of P-, 9 I. \& N. Dec. at 293; see Matter of P-, 8 I. \& N. Dec. 689, 690 (BIA 1960).

${ }^{89}$ Matter of $P_{-}, 9$ I. \& N. Dec. at 293.

${ }^{90} I d$. at 293-94; see Matter of P-, 8 I. \& N. Dec. at 690.

${ }^{91}$ Matter of P-, 9 I. \& N. Dec. at 294.

${ }^{92}$ Matter of $P_{-}, 8$ I. \& N. Dec. at 692.

${ }^{93}$ Matter of P-, 9 I. \& N. Dec. at 294.

${ }^{94}$ Ibid. (quoting United States ex rel. Piperkoff v. Esperdy, 267 F.2d 72, 75 (2d Cir. 1959)) (emphasis added).

${ }^{95}$ Matter of P-, 9 I. \& N. Dec. at 294 (quoting Piperkoff, 267 F.2d at 75).

${ }^{96}$ Matter of P-, 9 I. \& N. Dec. at 295.
} 
of the court's hearing on the petition, and the state district attorney had concurred that substantial questions had been raised by the petition. ${ }^{97}$ Given the content of the petition and the professed motivation of the court in granting the writ, the Attorney General had "no difficulty in concluding that the opportunity to recommend against deportation was not the court's 'sole basis' for vacating the March 1959 conviction[.]"98 As it was permissible to look to the October 1959 sentencing and judicial recommendation against deportation entered at that time, the Attorney General held that the statutory requirement was fulfilled and cancelled the deportation. ${ }^{99}$

Kennedy's opinion took a functional approach to a question with high-stakes consequences for the alien. Examining the arguments raised in the petition holistically, and giving a limiting interpretation to the Second Circuit's opinion in Piperkoff, Kennedy announced a rule that was to guide subsequent adjudicators in confronting similar post-conviction issues: where there is a constitutional or legal defect in the underlying proceeding, a grant of post-conviction relief will be effective for immigration purposes. ${ }^{100}$ In contrast, where the vacatur or relief is solely for the purposes of addressing the immigration consequences of the prior conviction or for other rehabilitative (i.e., non-substantive) purposes, the conviction will stand for immigration purposes. $^{101}$

\section{Citizenship and Expatriation}

Citizenship and expatriation were major issues of litigation throughout the 1950s and 1960s, culminating in a series of decisions before the Supreme Court. ${ }^{102}$ Kennedy himself confronted two such cases during his tenure as Attorney General.

The INA provided that a person "who is a national of the United States whether by birth or naturalization, shall lose his nationality by ... voting in a political election in a foreign state or participating in an election or plebiscite to determine the sovereignty over foreign territory[.]"103 The statute additionally provided for an irrebuttable presumption: "Any person who commits or performs any act specified in subsection (a) of this section shall be conclusively presumed to have done so voluntarily and without having been subjected to duress of any kind, if such person at the time of the act was a national of the state in which the act was performed and had been physically present in such state for a period or periods totaling ten years or more immediately prior to such act." 104

\footnotetext{
${ }^{97}$ Ibid.

${ }^{98}$ Ibid.

99 Ibid.

${ }^{100}$ See id. at 294; see also Matter of Ibarra-Obando, 12 I. \& N. Dec. 576, 589-90 (A.G. 1967).

${ }^{101}$ See Matter of Marroquin-Garcia, 23 I. \& N. Dec. 705, 713-17 (A.G. 2005); Matter of Luviano-Rodriguez, 23 I. \& N. Dec. 718, 720-21 (A.G. 2005); see also Matter of Roldan, 22 I. \& N. Dec. 512, 520-23 (BIA 1999).

102 See, e.g., Costello v. United States, 365 U.S. 265 (1961) (denaturalization proceeding); Trop v. Dulles, 356 U.S. 86 (1958) (action for a declaration of nationality following military desertion); Nishikawa v. Dulles, 356 U.S. 129 (1958) (same, in context of service in a foreign military); United States v. Zucca, 351 U.S. 91 (1956) (denaturalization proceeding based on membership in the Communist Party); United States v. Menasche, 348 U.S. 528 (1955) (on petition for naturalization); Shomberg v. United States, 348 U.S. 540 (1955) (same); Mandoli v. Acheson, 344 U.S. 133 (1952) (action against the Department of State for a declaration of citizenship).

103 8 U.S.C. $\$ 1481(\mathrm{a})(5)$ (1957).

104 8 U.S.C. $\S 1481$ (b) (1957).
} 
C-S- was born in Cuba to a father who was a United States citizen at birth, and thus C-Shimself "had a colorable claim to United States citizenship at birth" under then-governing law. ${ }^{105}$ Unfortunately, he was unaware of this potential claim until October 1959, when he was pursuing a visa. ${ }^{106}$ Before he learned of this possibility, he voted for elections to Cuba's national senate. ${ }^{107}$ The Board nonetheless terminated proceedings against him, noting that it had previously held "that a citizen of the United States could not lose United States citizenship by committing an act which would otherwise be the basis for a loss of citizenship, if, at the time the act was committed, he had no knowledge that he had a claim to United States citizenship." 108 Applying that rule resolved the case, since "where action was taken without knowledge that United States citizenship existed, the circumstances under which the [statutory] presumption was intended to operate do not exist."109

The INS sought reconsideration, but the Board denied the motion. ${ }^{110}$ The Service argued that the INS was enacted with knowledge of court cases "allegedly preclud[ing] the possibility of exempting a person who committed an act of expatriation without knowing that he was a United States citizen." "11 But as the Board noted in denying the motion, all cases cited by the government involved situations where the individual knew of their citizenship, the knowledge that was lacking in C-S-'s own case. ${ }^{112}$

The Attorney General agreed to review the case, but upheld termination of proceedings. He first held that Section 1481(b) is only relevant to questions of voluntariness and duress, and "[h]ence ... has no application to a case such as the present in which the acts were performed voluntarily but without knowledge of the individual's United States citizenship."113 In any event, if there were ambiguity in the statute, it should be resolved against expatriation: "The Supreme Court has emphasized that, where deprivation of the 'previous right of citizenship' is involved, 'the facts and the law should be construed as far as it reasonably possible in favor of the citizen." "114 "In the absence of clear and compelling statutory language," Kennedy was "unwilling to attribute to Congress an intention that the United States citizenship of an individual should be forfeited by reason of actions taken at a time when he was unaware of his citizenship." 115

A subsequent case, Matter of Picone, entailed a less beneficial result for the alien, even as Kennedy again announced a fairly liberal construction of the statute. ${ }^{116}$ The case concerned the interplay of United States law governing expatriation and Italian law governing the reacquisition of nationality. United States law provided that "any American citizen shall be deemed to have expatriated himself when he has been naturalized in any foreign state in conformity with its laws, or when he has taken an oath of allegiance to any foreign state. ${ }^{117}$ Italian law provided that "there

\footnotetext{
${ }^{105}$ Matter of C-S-, 9 I. \& N. Dec. 670, 670 (BIA 1961, 1962; A.G. 1962).

106 Ibid.

107 Ibid.

${ }^{108}$ Id. at 671 (citing Matter of C-A-, 9 I. \& N. Dec. 482 (BIA 1961)).

${ }_{109}$ Matter of $C-S-, 9$ I. \& N. Dec. at 671-72.

${ }^{110} I d$. at $672-75$.

${ }^{111} I d$. at 674 .

112 Ibid.

${ }^{113} \mathrm{Id}$. at 676.

114 Ibid. (quoting Nishikawa v. Dulles, 356 U.S. 129, 134 (1958)).

115 Matter of $C$-S-, 9 I. \& N. Dec. at 677.

11610 I. \& N. Dec. 139 (BIA 1962; A.G. 1963).

117 Act of March 2, 1907, 34 Stat. 1228, at $\S 2$.
} 
shall be recovery of Italian citizenship by one who having ceased to be an Italian citizen owing to the acquisition of foreign citizenship, has been resident in the kingdom for two years."118 Picone's father had been naturalized in the United States, and Picone thus sought a passport based on his assertion that he was a United States by birth. ${ }^{119}$ After the father's naturalization in 1992, however, he had returned to Italy and remained there from December 1925 through his death in $1958 .^{120}$ Picone was born in 1932, thus after the father's return to Italy and after the Italian law resulted in a de jure imposition of Italian citizenship. ${ }^{121}$ Additionally, facts were adduced to the effect that the father held no property in the United States, paid no taxes to the United States while paying taxes to the Italian government, held an Italian identity card, and definitely voted in national elections in 1951 and 1952, and likely in other elections dating as far back as $1934 .^{122}$

The Department of the State took the position that "as a matter of law, a person cannot become expatriated under a law which makes him a foreign national solely by operation of law, although there are overt acts voluntarily performed which may be regarded as acceptance of the foreign nationality." 123 The Board and INS rejected this extreme construction in favor of the "longstanding" position of the government, that "acquisition of Italian nationality" does not cause loss of United States citizenship, "unless the individual manifested a voluntary acceptance of Italian nationality by declaration, or overt act such as accepting employment by the Italian Government, accepting an Italian passport or identity card, voting in Italy, or joining an Italian political party." 124 The case was referred to the Attorney General for consideration of the legal issue: "whether to adhere to the long-standing administrative view that voluntary acceptance of naturalization obtained by operation of law results in expatriation under the Act of 1907 or to adopt the conclusion of the Department of State that in such circumstances the voluntary act cannot result in expatriation unless the act itself is specifically made an expatriating act by the statute."125

Kennedy was required to walk a tight-rope in interpreting the provision: United States "law should not be interpreted in such a way as to make it a trap for the unwary," caught by a foreign legal regime that automatically imposed citizenship based on extended residency. ${ }^{126}$ But the statutory language still placed limits on the breadth of any liberal interpretation, and there was no bar to applying the expatriation provision to naturalizations that occurred by operation of law. ${ }^{127}$ Residence alone, according to the Attorney General, should not be a sufficient basis for concluding that expatriation had occurred, except for the rare case where the individual evinced an intent to accept the foreign nationality at the point the residence commenced. ${ }^{128}$ The more difficult question was that posed by Picone's case - whether naturalization by operation of law, coupled with acts constituting a voluntary acceptance of that naturalization, was sufficient to find expatriation. Kennedy concluded that this was sufficient: "It is true, of course, that "rights of citizenship are not

\footnotetext{
118 Italian Nationality Law of June 13, 1912, at Article 9(3).

119 Matter of Picone, 10 I. \& N. Dec. at 145-46.

${ }^{120}$ See ibid.

${ }^{121}$ Id. at 146.

122 Ibid.

${ }^{123}$ Id. at $142-43$.

${ }^{124} \mathrm{Id}$. at 142 .

${ }^{125} \mathrm{Id}$. at 148 .

${ }^{126} I d$. at 149 .

${ }^{127}$ Id. at 150.

${ }^{128} \mathrm{Id}$. at $150-51$.
} 
to be destroyed by an ambiguity,' but when a United States citizen becomes naturalized by operation of law in a foreign country and by his subsequent course of conduct clearly manifests an intention to accept the rights and obligations that go with his new nationality, I do not believe that it does violence to the language of the Act of 1907 to hold that he has expatriated himself, notwithstanding that the tender of a new status under foreign law and its acceptance by the individual do not occur contemporaneously." "129 In so holding, however, Kennedy rejected the idea that acceptance should relate back in time to the commencement of the residency in the foreign country. Rather, "the act indicating acceptance of Italian nationality was probative only of intent at the time the act was performed," and thus that expatriation "should date from the act of acceptance." 130 Proceedings were remanded to assess the time-line and evidence in Picone's own case, to determine when expatriation may have occurred.

In both cases, Kennedy selected a reasonable interpretation of the statute that gave effect to the text, while erring on the side of the claimant. An awareness of the significance of the act being undertaken, or at least the voluntariness of the act itself in circumstances where the individual was reaping a benefit, was required. Loss of citizenship, or the inability to obtain U.S. citizenship by a child, could not be made to turn on anything less.

\section{Admissibility and Materiality of Misrepresentations}

Attorney General Kennedy decided three cases implicating the scope of the INA's inadmissibility provision relating to fraud in entry or the procurement of immigration documentation. Although often involving fact-intensive inquiries in application, Kennedy established base-line legal principles to govern the assessment of materiality, focusing on the ultimate question of whether the applicant would have nonetheless established eligibility for admission in the absence of the misrepresentation.

The first decision, issued soon after becoming Attorney General, involved consolidated cases under 8 U.S.C. $\$ 1182(a)(19)$, which rendered inadmissible and ineligible for a visa "[a]ny alien who seeks to procure, or has sought to procure, or has procured a visa or other documentation, or seeks to enter the United States, by fraud, or by willfully misrepresenting a material fact." In the case of S-, the alien had concealed his membership in the Communist party in order to procure a visa, but this had been found to be immaterial because his membership was "involuntary" and thus would not have constituted an independent ground of excludability. ${ }^{131}$ The Board upheld this determination, applying the rule that "a misrepresentation is not material, when made during proceedings for admission into the United States, if the alien would not have been denied a visa or excluded had he told the truth." 132 In the case of B-C-, the alien had procured multiple documents for himself and his wife using his nephew's identity. ${ }^{133}$ Exclusion was upheld, because "[i]n identity cases, a misrepresentation is always material; that is, the misrepresentation is material whether or not the alien gained any substantial benefit by it."134

\footnotetext{
${ }^{129}$ Id. at 152.

${ }^{130} \mathrm{Id}$. at 151 .

${ }^{131}$ Matter of S- \& B-C-, 9 I. \& N. Dec. 436, 436-38 (BIA 1960; A.G. 1961).

${ }^{132}$ Id.at 438 (citing Matter of G-M-, 7 I. \& N. Dec. 40, 74 (A.G. 1956)).

${ }^{133}$ Matter of $S-\& B-C-, 9$ I. \& N. Dec. at 441-42.

${ }^{134}$ Id. at 442 .
} 
Given a lack of clarity and some inconsistency in gauging materiality, the Attorney General referred the cases to himself for "a reexamination of the principles which should govern the disposition of such cases by the Executive Branch." 135 Basing his approach on an attempt to issue a decision "most consonant with the purposes and policies of the Immigration and Nationality Act," 136 Kennedy noted that construing this provision required him to balance "fair and humanitarian standards' ... with the need to "prevent the evasion of law by fraud[.]"'137 He first rejected the rule that a misrepresentation or fraud is material only if it goes to the excludability of the applicant. That rule "would deny subsection (19) any effect as an independent ground of exclusion, since in every case the alien would be excludable because of the existence of other grounds of exclusion and the fact that he made false statements would add nothing."138 Second, he rejected the distinction between fraud or misrepresentation in identity, and other forms of fraud and misrepresentation, concluding that "[o]n principle, I see no valid basis for distinguishing between different types of misrepresentations and for applying a special rule to cases involving identity." 139

In Kennedy's opinion, materiality should depend on two factors: first, whether "the alien is excludable on the true facts," and second, whether "the misrepresentation tended to shut off a line of inquiry which is relevant to the alien's eligibility and which might well have resulted in a proper determination that he be excluded." misrepresentation was material. ${ }^{141}$ If the answer to the second question is "no," then the misrepresentation was not material. ${ }^{142}$ If "yes," however, the adjudicator should then ask whether the inquiry, had it occurred, might have "resulted in a proper determination that the alien be excluded." "143 This inquiry would be fact dependent. In the cases at bar, Kennedy split in his application of materiality: S- was excludable, since omission of his Communist Party membership cut off a relevant line of inquiry, including a more detailed assessment of whether that membership was undertaken involuntarily or out of a sense of necessity, that would likely have affected the determination of admissibility; ${ }^{144} \mathrm{~B}-\mathrm{C}$ - was not excludable, as he was more likely than not admissible under his own name, and thus the use of his nephew's name in the procurement of documentation did not shut off a line of inquiry that may have otherwise produced a determination of inadmissibility. ${ }^{145}$

Kennedy applied Matter of $S$ - \& $B$ - $C$ - in a subsequent case, which also presented the issue of whether a materiality determination made in a parallel criminal proceeding was dispositive of the materiality issue in the inadmissibility context. ${ }^{146}$

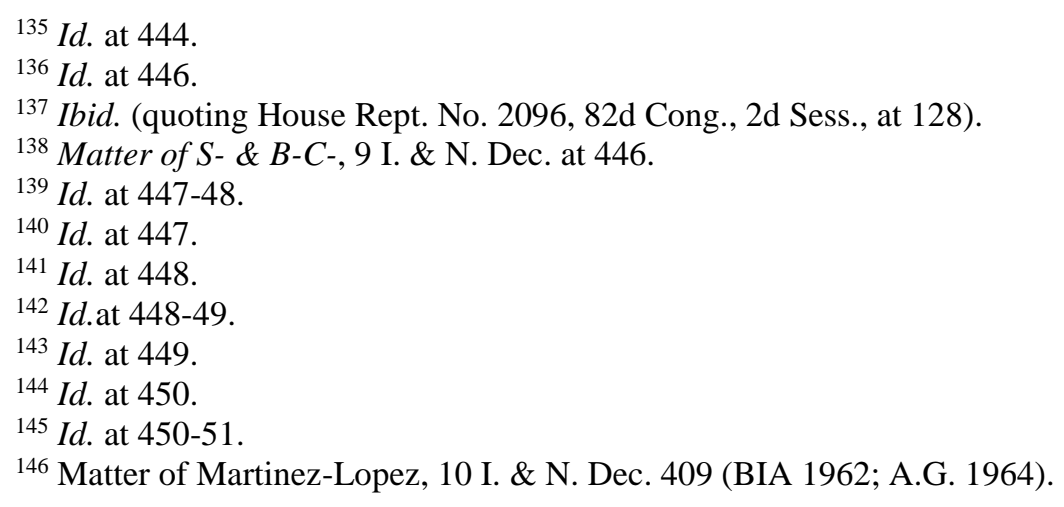


Martinez-Lopez applied for a visa with a legitimate letter of support from a brother legally resident in the United States, and a fraudulent letter offering employment in the United States, which unknown to the applicant was also a forgery (although he knew there was no real offer of employment). ${ }^{147}$ This scheme was uncovered, and Martinez-Lopez, along with his brother and a cousin, were convicted of violating 18 U.S.C. $§ 1001$, which provided: "Whoever, in any matter within the jurisdiction of any department or agency of the United States knowingly and willfully falsifies, conceals or covers up by any trick, scheme, or device a material fact, or makes any false, fictitious or fraudulent statements or representations, or makes or uses any false writing or document knowing the same to contain any false, fictitious or fraudulent statement or entry, shall be fined not more than $\$ 10,000$ or imprisoned not more than five years, or both." In order to convict, the government had to prove - and did prove - the materiality of the misrepresentation and fraud. Martinez-Lopez was subsequently charged with deportability as an alien excludable at the time of admission under 8 U.S.C. $§ 1182(\mathrm{a})(19)$, based on fraud or misrepresentation. ${ }^{148}$ In so charging Martinez-Lopez, the INS argued that the resolution of the materiality question in the criminal proceeding definitely established the materiality of the misrepresentation for purposes of the immigration laws.

Kennedy disagreed. He started from the premise that determinations of deportation and exclusion are the exclusive purview of the INS by law. ${ }^{149}$ According to Kennedy, there was then "a basis for the argument that in the instant case the judicial finding of materiality could not, as a matter of law, relieve the special inquiry officer from his duty of making an independent determination of materiality." 150 Regardless of that independent obligation, however, "there was no true identity of issues in the criminal case and the deportation proceeding." 151 An identity of issues would occur only if materiality had the same meaning under both the criminal code and the immigration laws. ${ }^{152}$ Materiality, as used in 18 U.S.C. $\S 1001$, addressed only "whether the misrepresentation was "calculated to induce action or reliance by an agency of the United States." 153 Materiality under the INA was distinct, as the Attorney General had previously clarified in Matter of $S$ - \& B-C-. Applying that test, Kennedy concluded that the misrepresentation was not material. Under the true facts, Martinez-Lopez would not have been excludable on any basis, including that of being a "public charge." the effect of shutting "off a line of inquiry relevant to his eligibility for a visa," it did not appear that any such inquiry "would have resulted in a proper determination that the respondent was excludable." 155

\footnotetext{
${ }^{147}$ Id. at $409-10$.

${ }^{148}$ See 8 U.S.C. $\$ 1251(a)(1)(1957)$.

149 See 8 U.S.C. $§ 1252(b)$ (1957).

${ }^{150}$ Matter of Martinez-Lopez, 10 I. \& N. Dec. at 419-20.

${ }^{151}$ Id. at 420.

152 Ibid. ("The determination in the criminal case to the effect that the work offer was 'material' might be considered to be binding in the deportation proceedings only if the word 'material' has the same meaning in prosecutions under 18 U.S.C. $\S 1001$ as in deportation proceedings.").

${ }^{153} \mathrm{Ibid}$. (quoting Brandow v. United States, 268 F.2d 559, 565 (1959)).

${ }^{154}$ Matter of Martinez-Lopez, 10 I. \& N. Dec. at 421-23.

${ }^{155} I d$. at 423.
} 
Finally, in Matter of $S$-, Kennedy addressed the interplay between excludability under the statute based on fraud and the statute of limitations governing the Attorney General's rescission of adjustment-of-status. ${ }^{156}$ Congress provided a route to permanent residency for an alien previously admitted to the United States: "The status of an alien ... may be adjusted by the Attorney General ... to that of an alien lawfully admitted for permanent residence if (1) the alien makes an application for such adjustment, (2) the alien is eligible to receive an immigrant visa and is admissible to the United States for permanent residence, and (3) an immigrant visa is immediately available to him at the time his application is approved[.]"157 The statute also provided for rescission of a previously granted adjustment: "If, at any time within five years after the status of a person has been otherwise adjusted under the provisions of section $245 \ldots$ of this Act ... it shall appear to the satisfaction of the Attorney General that the person was not in fact eligible for such adjustment of status, the Attorney General shall rescind the action taken granting an adjustment of status to such person and cancelling deportation in the case of such person if that occurred and the person shall thereupon be subject to all provisions of this Act to the same extent as if the adjustment of status had not been made." "158 Did the five-year statute of limitations for rescission also bar the institution of exclusion proceedings against an alien under 8 U.S.C. § 1182(a)(19)?

The Board concluded that Section 1256 applied to bar any subsequent exclusion proceeding premised on fraud in the process of procuring that status. It held that there was "no logical reason why Congress which desired to protect this status by a statute of limitations, even though the status had been acquired by one who was not eligible, should wish to withdraw that protection because the alien had left the country and replied for admission on the basis of the very adjustment of status which they had protected."159

The Attorney General disagreed with this liberal construction. ${ }^{160}$ In his view, the conferral of permanent residency under Section 245 was not meant to confer such a broad benefit on the alien, the effective insulation from immigration consequences of all that came before acquisition of that status. That section "was not designed either to 'benefit the alien who has entered the United States in violation of the law' or to 'affect the statutory standards of eligibility for immigration into the United States." 161 Clearly Congress placed a temporal limit on when that status could be rescinded by the Attorney General based on ineligibility at the time of adjustment. ${ }^{162}$ But Kennedy could not "agree that, in performing this narrow function, the time limitation imposed on rescission by section 246 was intended to be read as qualifying the express authority provided by the Act to deport or exclude aliens on proper grounds without time limitation. Such an extreme interpretation would require either specific statutory language or at least a clear indication in the legislative history that Congress intended the statute to be so read. There is neither." 63 Thus, the Attorney General read the statute as not barring "an exclusion

\footnotetext{
1569 I. \& N. Dec. 548 (BIA 1961, 1962; A.G. 1962).

157 8 U.S.C. $\S 1255(\mathrm{a})$ (1960).

1588 U.S.C. $\$ 1256$ (1960).

${ }^{159}$ Matter of $S-, 10$ I. \& N. Dec. at 553.

${ }^{160} \mathrm{Ibid}$. ("I cannot agree that an adjustment of status under section 245 and the five-year limitation on rescission provided in section 246 have the effects attributed to them by the special inquiry officer and the Board of Immigration Appeals.").

161 Id. at 554 (quoting S. Rept. No. 2133, 85th Cong., 2d Sess., at 2).

162 See 8 U.S.C. $\$ 1256$ (1960).

${ }^{163}$ Matter of $S$-, 10 I. \& N. Dec. at 554-55.
} 
proceeding based upon the alleged fraudulent procurement of an entry visa prior to his adjustment of status," even if more than five years had lapsed since the adjustment itself. ${ }^{164}$

Kennedy's opinions in these cases were more of a mixed bag for the alien. He remained focused, as always, on the human dimension of these cases and the need to interpret the law in a practical fashion. As he noted in Matter of $S-\& B-C-$-, "[s]hutting off the opportunity to come to the United States actually is a crushing deprivation to many prospective immigrants. Very often it destroys the hopes and aspirations of a lifetime, and it frequently operates not only against the individual immediately but also bears heavily upon his family in and out of the United States."165 These hopes should color the interpretation given, but could not dictate it, just as the application of even a liberal construction will not always result in relief. This principle animates the core of the decisions addressing misrepresentation, focused as they are on whether the misrepresentation was collateral to the admission determination or rather concealed a basis on which the alien could or would have been excluded. Two aliens found relief in this interpretation, another not. So, too, with S- and the question of excludability and rescission. This may be the least liberal construction Kennedy gave to a provision of the INA, but it is eminently reasonable in light of the purpose of the statute and its text. Adjustment of status was and is a benefit to be granted, and one that may be rescinded in certain circumstances. But the granting of that status is not a prospective free-pass for all immigration transgressions that preceded it. It is of course a strict rule that may entail particularly harsh consequences for long-term residents, but it is more in consonance with the law as written than the Board's alternative construction.

* $\quad * \quad *$

Kennedy's approach across this whole range of cases can be succinctly summarized. Where the intent of Congress and the language it used was clear, he followed the statute to its letter even where that interpretation may have entailed harsher consequences than other ostensibly reasonable interpretations. But where Congress provided space for true interpretation, and either a liberal construction of the statute or a stricter interpretation could both be deemed reasonable, Kennedy invariably favored liberal construction, animated by a humane understanding of the stakes for the individual.

\section{THE REFERRAL AUTHORITY IN RECENT DEMOCRAT ADMINISTRATIONS}

Contemporary uses of the referral authority have varied considerably based on the political identity of the administration in power. As noted in the introduction, recent Republican administrations, most notably the George W. Bush and Trump Administrations, have used the authority as an integral component in advancing their immigration policy objectives. In contrast, use of the authority has been virtually nonexistent in contemporary Democrat administrations, and when it has been used it has been largely for non-substantive dispositions, i.e., in cases where the Attorney General is performing a more administrative function rather than an interpretive function. This section addresses the use of the referral authority in the two most recent Democrat

\footnotetext{
164 Id. at 557.

165 Matter of $S$ - \& B-C-, 9 I. \& N. Dec. at 446 (citing Report of the President's Commission on Immigration and Naturalization 177 (1953)).
} 
administrations, highlighting the de minimis role it played in the advancement of immigration policy during this time.

\section{A. Referral in the Clinton Administration}

Attorney General Janet Reno issued four decisions upon referral during her service in the Clinton Administration. Three of these decisions were effectively administrative, referring a decision by the Board for her review, but ultimately remanding based on intervening circumstances. The fourth decision, dealt with in this section first, was substantive, but met with a frosty reception in the courts of appeals and ultimately failed to prevail as a guiding interpretation of the relevant provision.

In 1996, as part of a broader overhaul and reform of the immigration statute, Congress passed the Antiterrorism and Effective Death Penalty Act. ${ }^{166}$ The AEDPA amended section 212(c) of the INA by adding a final sentence, providing that " $[\mathrm{t}]$ his section shall not apply to an alien who is deportable by reason of having committed any" of a number of enumerated criminal offenses. ${ }^{167}$ Prior to the enactment of AEDPA, Soriano was convicted of attempted criminal sale of a controlled substance, which rendered him deportable under Section 1251(a)(2)(A)(iii), and an immigration judge declined to waive deportability under section 212(c) in the exercise of his discretion. ${ }^{168}$ While his administrative appeal was pending with the Board, AEDPA was enacted, raising two questions regarding the reach of the amendment to section 212(c): did it apply to all pending proceedings, and even if so, did it also apply to all pending applications for relief in which there had not yet been a final decision at the time of enactment? On the first question, the Board held that the lack of an effective date in the statute itself meant that it applied without limitation to all proceedings, not just those instituted after its effective date. ${ }^{169}$ Other provisions of AEDPA had clearly indicated effective dates, if different than the enactment date, and the lack of such language regarding Section 440(d) led inexorably to the conclusion that it applied to all proceedings without limitation. ${ }^{170}$ The opposite inference, however, governed when assessing what applications the amendment applied to. The Board noted that other limitations or changes to provisions providing for discretionary relief applied to applications filed "before, on, or after" the effective date of AEDPA. ${ }^{171}$ No such language was included in Section 440(d). The Board thus "interpret[ed] Congress' omission of the 'before, on, or after' language in section $440(\mathrm{~d})$ to indicate its intent that aliens with applications pending on April 24, 1996, should not be statutorily barred from section 212(c) relief by operation of the AEDPA." ${ }^{172}$ Soriano thus remained statutorily eligible for a waiver under section 212(c), although the Board did uphold the immigration judge's denial of that waiver in the exercise of discretion. ${ }^{173}$

\footnotetext{
166 Pub. L. No. 104-132, 110 Stat. 1214 (1996).

167 AEDPA $\S 440($ d), 110 Stat. at 1277 (referencing offenses "covered in" 8 U.S.C. $\S \S 1251(\mathrm{a})(2)(\mathrm{A})(\mathrm{iii}),(\mathrm{B}),(\mathrm{C})$, and (D), and "any offense covered by" 8 U.S.C. $\S 1251(\mathrm{a})(2)(\mathrm{A})(\mathrm{ii})$ "for which both predicate offenses are covered by" 8 U.S.C. $\S 1251(\mathrm{a})(2)(\mathrm{A})(\mathrm{i})$.

168 Matter of Soriano, 21 I. \& N. Dec. 516, 517-18 (BIA 1996; A.G. 1997).

${ }^{169} I d$. at 519.

${ }^{170}$ Ibid.

${ }^{171}$ Id. at 519-20 (citing AEDPA $\S 413(\mathrm{~g}), 110$ Stat. at 1269-70).

${ }^{172}$ Id. at 520.

${ }^{173} I d$. at 521 .
} 
Attorney General Reno disapproved of the Board's conclusion that Section 440(d) did not apply to all applications pending as of AEDPA's effective date, "conclud[ing] that the amendment to INA 212(c) ... applies to proceedings ... in which an application for relief under section 212(c) was pending when AEDPA was signed into law."174 The Attorney General based this holding on her conclusion that the law did not act retroactively. First, the "relief sought in a section 212(c) application, waiver of inadmissibility, is prospective in nature."175 Second, "Congress's modification of section 212(c) operates to eliminate the discretionary authority of the Attorney General to grant relief in certain cases, and, thus, its effect is to remove jurisdiction," which constituted an exception to the presumption against retroactive effect. ${ }^{176}$ There was, then, no compelling argument that application of section 440(d) to Soriano's pending application for relief would involve a retroactive effect. ${ }^{177}$ Nonetheless, the Attorney General did fashion a limited remedy for similarly situated aliens: "to eliminate even the remote possibility that an alien who had a colorable defense to deportability may have conceded deportability in reliance on the availability of section 212(c) relief, I direct the EOIR to reopen cases upon petition by an alien who conceded deportability before the effective date of AEDPA for the limited purpose of permitting him or her to contest deportability."178

Matter of Soriano had a short shelf-life. It was rejected in the federal courts of appeals almost immediately, with those courts concluding that Congress had not intended the amendment to apply retroactively to cases pending at the time AEPDA was enacted. ${ }^{179}$ The Department of Justice subsequently promulgated regulations adopting an even more generous view of the application of the amendments than the Board's initial decision, exempting all pending proceedings from the new bar, not just those where an application for relief had been filed prior to the effective date of AEDPA. ${ }^{180}$ And, of course, the Supreme Court ultimately concluded that section "212(c) relief remains available for aliens ... whose convictions were obtained through plea agreements and who, notwithstanding those convictions, would have been eligible for 212(c) relief at the time of their pleas under the law then in effect."181

Twice more Attorney General Reno issued decisions tied to amendments made to the INA in 1996, this time by the Illegal Immigration Reform and Immigrant Responsibility Act, but each decision was more a matter of administration than substance. In Matter of Farias, the Board upheld an immigration judge's decision granting a waiver of deportability to an alien charged with alien smuggling, because at the time she sought the waiver she was married to the individual she had assisted in smuggling. ${ }^{182}$ The Board's interpretation of the waiver provision, 8 U.S.C. 1251(a)(1)(E)(iii), was permissive, allowing a waiver even in circumstances where the alien was

\footnotetext{
${ }^{174}$ Id. at 534.

${ }^{175} \mathrm{Id}$. at 537.

176 Ibid.

${ }^{177}$ Id. at 540.

178 Ibid.

${ }^{179}$ See, e.g., Henderson v. INS, 157 F.3d 106, 129-30 (2d Cir. 1998); Goncalves v. Reno, 144 F.3d 110, 126-33 (1st Cir. 1998).

${ }^{180}$ See Margaret H. Taylor, Behind the Scenes of St. Cyr and Zadvydas: Making Policy in the Midst of Litigation, 16 GEO. IMMigR. L.J. 271, 287 (2002) (citing 66 Fed. Reg. 6436 (Jan. 22, 2001)).

${ }^{181}$ INS v. St. Cyr, 533 U.S. 289, 326 (2001); see Patrick J. Glen, Interring the Immigration Rule of Lenity, ** NEB. L. REV. **,** (2021).

18221 I. \& N. Dec. 269, 271-74 (BIA 1996).
} 
not married to the qualifying individual at the time the smuggling occurred. ${ }^{183}$ IIRIRA amended this statutory provision to explicitly provide that the covered familial relationship must exist "at the time of the offense." 184 Attorney General Reno referred and vacated the Board's decision, remanding for further consideration of the applicant's eligibility for a waiver in light of IIRIRA's amendment; a waiver that was ultimately denied given the amended language and the fact that the applicant had not been married to the individual at the time of her smuggling offense. ${ }^{185}$

In Matter of $N-J-B-$, the majority of the Board, sitting en banc, determined that another provision of IIRIRA, the so-called "stop-time rule" for calculating periods of continuous physical presence and residence in the United States, could be applied to pretermit an application for suspension of deportation, notwithstanding the fact that proceedings against the alien had been instituted before the enactment and effective date of IIRIRA. ${ }^{186}$ The Attorney General referred and vacated the Board's decision in July 1997, but took no adjudicatory action. ${ }^{187}$ The referral was likely precipitated by the administration's disagreement with the Board's decision, and its intent to resolve the matter through the introduction of clarifying legislation. ${ }^{188}$ President Clinton did subsequently sign into law the Nicaraguan Adjustment and Central American Relief Act, ${ }^{189}$ which revised certain parts of IIRIRA's transitional rules, including the rule on which the Board had based its decision in Matter of $N-J-B-{ }^{190}$ For the most part, however, the relevant revisions had the effect of codifying the Board's vacated majority decision in Matter of $N-J-B-$, and the Board thus effectively reissued that holding in Matter of Nolasco-Tofino, holding that the amended rule applied to all charging documents whenever issued. ${ }^{191}$

Along with its amendments to IIRIRA's transitional rules, however, NACARA also provided for a new relief provision that was meant to benefit certain qualifying aliens from Central American countries, including Nicaragua (N-J-B-'s country of citizenship). ${ }^{192}$ Congress's

\footnotetext{
183 See id:; see also 8 U.S.C. $\S$ 1251(a)(1)(E)(iii) ("The Attorney General may, in his discretion for humanitarian purposes, to assure family unity, or when it is otherwise in the public interest, waive application of clause (i) [pertaining to deportability] in the case of any alien lawfully admitted for permanent residence if the alien has encouraged, induced, assisted, abetted, or aided, only the alien's spouse, parent, son, or daughter (and no other individual) to enter the United States in violation of law.").

${ }^{184}$ Matter of Farias, 21 I. \& N. Dec. at 280.

185 See id. at 282.

18622 I. \& N. Dec. 1057, 1063-68 (BIA 1997; A.G. 1997, 1999); see Patrick J. Glen \& Alanna R. Kennedy, The Strange and Unexpected Afterlife of Pereira v. Sessions, 34 GEO. IMMIGR. L.J. 1, 13 (2019) (recounting the history of Matter of $N-J-B-$ ).

187 See Matter of N-J-B-, 22 I. \& N. Dec. at 1088.

188 See National Immigration Law Center, Immigrants' Rights Update, Vol. 11(5), at 1 (July 23, 1997) ("Reno announced in a press statement that the Clinton administration will introduce legislation to ensure that individuals who applied for suspension of deportation prior to the IIRIRA's April 1, 1997, effective date ... continue to be eligible for suspension of deportation.").

${ }^{189}$ Pub. L. No. 105-100, tit. II, 111 Stat. 2193 (1997), amended by Pub. L. No. 105-139, 111 Stat. 2644 (1997).

190 See Matter of Nolasco-Tofino, 22 I. \& N. Dec. 632 (BIA 1999).

191 See Angel-Ramos v. Reno, 227 F.3d 942, 946-47 (7th Cir. 2000); Patricia Flynn \& Judith Patterson, Five Years Later: Fifth Circuit Case Law Developments Under the Illegal Immigration Reform and Immigrant Responsibility Act, 53 BAYLOR L. REV. 557, 588-89 (2001).

192 See Edward R. Grant, Laws of Intended Consequences: IIRIRA and Other Unsung Contributors to the Current State of Immigration Litigation, 55 CATH. U.L. REV. 923, 927 (2006) (noting effective amnesty and relief provisions of NACARA); Elwin Griffith, The Transition Between Suspension of Deportation and Cancellation of Removal for Nonpermanent Residences Under the Immigration and Nationality Act: The Impact of the 1996 Reform Legislation, 48 DRAKE L. REV. 79, 129-30 (1999) (similar).
} 
amendments foreclosed one avenue of relief for N-J-B-, but opened up another, and in August 1999, Attorney General Reno remanded the case to the Board for it to consider an intervening motion to reopen filed by the alien regarding relief under the newly enacted statutory provisions of NACARA pertaining to adjustment of status. ${ }^{193}$

Finally, Attorney General Reno was the first of three Attorneys General to refer the case of R-A-, a Guatemalan woman who had been the victim of severe domestic violence and sought asylum and related protection in the United States. ${ }^{194}$ An immigration judge granted asylum, making two determinations: first, that R-A- was persecuted on account of her membership in a particular social group, defined as "Guatemalan women who have been involved intimately with Guatemalan male companions, who believe the women are to live under male domination," "95 and second, that "through [R-A-'s] resistance to his acts of violence, her husband imputed to the respondent the political opinion that women should not be dominated by men, and he was motivated to commit the abuse because of the political opinion he believed her to hold."196 The Board reversed on both grounds. Focusing on the first here, the Board concluded that the proposed social group was not shown to be a "group that is recognized and understood to be a societal faction, or is otherwise a recognized segment of the population, within Guatemala. [R-A-] has shown neither that the victims of spouse abuse view themselves as members of this group, nor, most importantly, that their male oppressors see their victimized companions as part of this group." "197 Nor did the Board view members of the proposed group as at risk because of their membership in the proffered group: "If group membership were the motivation behind his abuse, one would expect to see some evidence of it manifested in actions towards other members of the same group.... On the basis of this record, we perceive that the husband's focus was on the respondent because she was his wife, not because she was a member of some broader collection of women, however defined, whom he believed warranted the infliction of harm."198 The Board did note that the INS was free to halt deportation in the exercise of its discretion, but that R-A-'s recourse to asylum was unavailing. ${ }^{199}$

The most immediate reaction to the Board's decision was regulatory. In December 2000, the Department of Justice promulgated a proposed rule to amend certain regulations pertaining to asylum eligibility, motivated in large part by a desire to reverse the Board's reasoning. ${ }^{200}$ The proposed rule clarified that there is no requirement that a persecutor seek to harm all members of a particular social group. ${ }^{201}$ The rule also proposed case-by-case adjudications for particular social groups premised on private harm based on "broadly applicable principles," leaving further refinement for successive subsequent adjudications. ${ }^{202}$ In light of the proposed rule, Attorney

\footnotetext{
193 See Matter of N-J-B-, 22 I. \& N. Dec. at 1088-89.

194 See Matter of R-A-, 22 I. \& N. Dec. 906, 907 (BIA 1999).

195 Id. at 911.

196 Ibid.

${ }^{197}$ Id. at 918 .

${ }^{198} I d$. at $920-21$.

199 Id. at 928 ("The solution to the respondent's plight does not lie in our asylum laws as they are currently formulated.").

200 See 65 Fed. Reg. 76,588, 76,588 (Dec. 7, 2000).

${ }^{201} \mathrm{Id}$. at 76,592-593; see id. at 76,597-598 ("Evidence that the persecutor seeks to act against other individuals who share the applicant's protected characteristic is relevant and may be considered but shall not be required.").

${ }^{202}$ Id. at 76,595.
} 
General Reno vacated the Board's decision on the eve of the Bush Administration and remanded for reconsideration, directing the Board to stay further consideration until the proposed rule had been finalized. ${ }^{203}$ Attorneys General Ashcroft and Mukasey subsequently referred the case, as the regulatory process stagnated, with the latter ultimately directing the Board to adjudicate the case. ${ }^{204}$ R-A- ultimately obtained asylum based on stipulations by the government, ${ }^{205}$ although the domestic-violence asylum issue had a less satisfying resolution for immigration advocates: Attorney General Sessions' decision in Matter of $A-B$-, which returned to the main themes the Board had enunciated in the initial decision in Matter of $R-A-{ }^{206}$

In eight years, the Clinton Administration never really utilized Attorney General referral as a tool to implement its immigration policy agenda. Part of the reason is evident from the face of the decisions that Attorney General Reno actually did issue, all of which addressed in one way or another intervening amendments to the immigration laws: statutory reform was the order of the day. Both AEDPA and IIRIRA were enacted in 1996, and constituted dramatic reforms to the existing statutory structure. ${ }^{207}$ Narrower and more targeted statutes were enacted in 1994, 1997, and 1998, as well. ${ }^{208}$ The Clinton-era referrals were largely a clean-up operation following the major 1996 enactments: remands for further consideration in cases where Board precedent had been overruled or placed into question. In this context, Matter of Soriano stands out as an attempt to interpret a provision of the 1996 amendments, but even that related only to the temporal scope of what Congress enacted and not to a truly substantive issue of interpretation with prospective importance.

Noting the legislative context of the Clinton Administration does not excuse, necessarily, the failure to integrate referral into its policy-making apparatus. It is true that any administration will have limited capacity to address each and every conceivable issue that may arise, and that it did make sense to focus time and energies on the broader statutory reforms enacted during this period. But by doing so, the Clinton Administration left issues on the table that would have been amenable to resolution through referral. The domestic-violence particular social group question was certainly one where the administration could have taken a harder adjudicatory line rather than rely on the promulgation of a proposed rule in the waning days of the Clinton presidency. Chinese family-planning policies and to what extent those who opposed such policies should be able to

\footnotetext{
${ }^{203}$ Matter of R-A-, 22 I. \& N. Dec. 906, 906 (A.G. 2001).

${ }^{204}$ See Matter of R-A-, 23 I. \& N. Dec. 694 (A.G. 2005) (referring and remanding "for reconsideration following final publication of the proposed rule published at 65 Fed. Reg. 76,588 (Dec. 7, 2000). The BIA should reconsider the decision in light of the final rule."); Matter of R-A-, 24 I. \& N. Dec. 629, 630-31 (A.G. 2008) ("In light of these developments and the fact that the proposed rule cited by Attorney General Reno never has been made final, I have decided to lift the stay so that the Board can revisit the issues in Matter of $R$ - $A$ - and related cases and issue new decisions. Accordingly, the Board should now proceed as it sees fits with its reconsideration of Matter of R-A- and the other cases involving similarly situated aliens.").

${ }^{205}$ See Barbara R. Barreno, In Search of Guidance: An Examination of Past, Present, and Future Adjudications of Domestic Violence Asylum Claims, 64 VAND. L. REV. 225, 249 (2011).

${ }^{206}$ Matter of A-B-, 27 I. \& N. Dec. 316, 333-40 (A.G. 2018).

${ }^{207}$ See, e.g., Goncalves, 144 F.3d at 115 ("Congress substantially altered the immigration landscape by enacting two significant statutes, AEDPA and IIRIRA.”).

${ }^{208}$ See Haitian Refugee Immigration Fairness Act of 1998, Pub. L. No. 105-277, 112 Stat. 2681-538 (1998); Nicaraguan Adjustment and Central American Relief Act, Pub. L. No. 105-100, tit. II, 111 Stat. 2193 (1997), amended by Pub. L. No. 105-139, 111 Stat. 2644 (1997); Immigration and Nationality Technical Corrections Act of 1994, Pub. L. No. 103-416, 108 Stat. 4305 (1994).
} 
establish eligibility for asylum is another area where the administration punted on adjudicatory resolution. $^{209}$ Here, Congress ultimately resolved the question in 1996 with an amendment to the refugee definition. ${ }^{210}$ In short, the administration's focus on statutory reform obscured smaller steps that could have been taken by the administration, in conjunction with those broader ends, to effectuate its immigration policy.

\section{B. Referral in the Obama Administration}

In contrast to the Clinton Administration, which occurred during a long period in which Attorney General referral was a rarely used mechanism, the Obama Administration took office on the heels of one of the most active users of the authority since enactment of the original Immigration and Nationality Act of 1952. The George W. Bush Administration utilized the authority to issue sixteen decisions during its eight years in office, a pace not seen since the days of Eisenhower, Kennedy, and Johnson. ${ }^{21}$ With attempts at statutory reform stagnating in this period, unlike the Clinton era, referral could have been a natural forum through which to implement policy preferences through interpretation of key provisions in the INA. Instead, despite being well aware of the authority's possibilities, the Obama Administration failed to take advantage of the mechanism.

Attorney General referral was on the agenda as soon as the Obama Administration took office, thanks to two decisions issued by Attorney General Mukasey in the closing six months of the Bush Administration, Matter of Compean and Matter of Silva-Trevino. In Matter of Compean, Attorney General Mukasey issued a decision addressing two dimensions of ineffective assistance of counsel claims in removal proceedings. ${ }^{212}$ First, addressing whether there was a Due Process right to effective assistance of counsel, he concluded that no such Fifth Amendment right existed, as that Amendment apples only against the government, and any ineffective assistance of counsel would be by private counsel with an insufficient nexus to state action. ${ }^{213}$ Second, he nonetheless

\footnotetext{
${ }^{209}$ See Julie Tang, The United States' Immigration Laws: Prospects for Relief for Foreign Nationals Seeking Refuge from Coercive Sterilization or Abortion Practices in Their Homelands, 15 ST. LouIS U. PUB. L. REV. 371, $384-85$ (1996) (noting referral of family-planning issues to Attorney General Reno, as well as her refusal to consider the question on the merits); Gao v. Waters, 869 F.Supp. 1474, 1478 n.6 (N.D. Cal. 1994) (noting rescission of the order granting review); see also Dong v. Slattery, 870 F.Supp. 53, 59 (S.D.N.Y. 1994) (Mukasey, J.) ("the Attorney General has the express authority to formally review any BIA decision, and thus has been free to modify or overrule [Matter of] Chang since it was decided five years ago. In the intervening years, the BIA has consistently applied and explicitly endorsed Chang, while the Attorney General conspicuously refrained from repudiating Chang.").

${ }^{210}$ See 8 U.S.C. $\$ 1101(\mathrm{a})(42)(B)$ ("a person who has been forced to abort a pregnancy or to undergo involuntary sterilization, or who has been persecuted for failure or refusal to undergo such a procedure or for other resistance to a coercive population control program, shall be deemed to have been persecuted on account of political opinion, and a person who has a well founded fear that he or she will be forced to undergo such a procedure or subject to persecution for such failure, refusal, or resistance shall be deemed to have a well founded fear of persecution on account of political opinion."); see also Brian Edstrom, Assessing Asylum Claims from Children Born in Violation of China's One-Child Policy: What the United States Can Learn from Australia, 27 WIS. INT'L L.J. 139, 155-56 (2009) (noting addition of subsection (B) to Section 1101(a)(42) and the desire to target claims of persecution arising under China's one-child policy).

${ }^{211}$ See Gonzales \& Glen, supra note 4, at 857-58.

21224 I. \& N. Dec. 710 (A.G. 2009).

${ }^{213}$ Id. at 716-20 (citing, inter alia, Mathews v. Eldridge, 424 U.S. 319, 332 (1976); Jackson v. Metropolitan Edison Co., 419 U.S. 345, 351 (1974)); see Patrick J. Glen, The Nonconstitutional Character of Ineffective Assistance of
} 
concluded that the Board retained discretion to reopen proceedings based on a claim of ineffective assistance of counsel, and imposed a new substantive and procedural framework to govern such claims, superseding the prior standards the Board had announced in Matter of Lozada. ${ }^{214}$

Attorney General Holder vacated the decision soon after assuming office, concluding that the constitutional ruling was unnecessary to the decision, and that rule-making would be instituted in order to establish a framework for consideration of such claims going forward. ${ }^{215}$ The Attorney General also directed the Board to apply the extant Lozada requirements in the interim, while directing Department of Justice litigators to maintain their pre-Compean litigation position in the courts of appeals (a position that argued there is no constitutional right to effective assistance of counsel in immigration proceedings, and thus no Due Process violation where counsel performs ineffectively). ${ }^{216}$ Although mostly a place-holder decision, the opinion also resolved an open issue, holding that the Board does have discretion to consider an ineffective assistance of counsel claim that arises after entry of the final order, for instance, in the failure to timely file a petition for review with the appropriate court of appeals. ${ }^{217}$ The regulatory fix noted in the decision was never finalized.

Matter of Silva-Trevino had a longer post-Bush Administration existence. ${ }^{218}$ At issue was whether immigration adjudicators were bound to the strictures of the categorical approach in determining whether an alien had been convicted of a "crime involving moral turpitude." The categorical approach directs adjudicators to "look "not to the facts of the particular prior case," but to whether the "'crime of conviction' categorically fits within the 'generic' federal definition of a corresponding" offense. ${ }^{219}$ In cases where the statute of conviction is indivisible, this is straightforward and requires only a comparison of the statutory elements with those of the generic offense. ${ }^{20}$ If a single statute instead sets out multiple, distinct offenses, an adjudicator may apply the so-called "modified categorical approach," which permits consultation of a limited range of documents, "such as indictments and jury instructions, to determine which alternative [offense]

Counsel Claims in Immigration Proceedings: A Brief Comment on Afanwi v. Mukasey, 82 S. CAL. L. REV. POSTSCRIPT 1, 8-10 (2008).

${ }^{214}$ Matter of Compean, 24 I. \& N. Dec. at 727-28, 732-39; see Daniel Changshik Moon, Current DevelopmentDevelopment in the Judicial Branch-Former Attorney General Mukasey Eliminates Right to Effective Assistance of Counsel in Immigration Proceedings, 23 GEO. IMMIGR. L.J. 245, 248-50 (2008).

${ }^{215}$ Matter of Compean, 25 I. \& N. Dec. 1, 2-3 (A.G. 2009).

${ }^{216}$ Id. at 3; see Brief for the Respondent in Opposition at 16-17, Merchant v. Holder, 134 S. Ct. 1276 (2014) (No. 13400), 2013 WL 6913345; Brief for the Respondent at 10-12, Afanwi v. Holder, 558 U.S. 801 (2009) (No. 08-906), 2009 WL 2625869.

${ }^{217}$ Matter of Compean, 25 I. \& N. Dec. at 3; see Jean Pierre Espinoza, Ineffective Assistance of Counsel in Removal Proceedings, Matter of Compean, and the Fundamental Fairness Doctrine, 22 FLA. J. INT'L L. 65, 92 (2010) ("Holder temporarily decided an issue not decided prior to Compean. The BIA had not yet resolved whether its discretion to reopen removal proceedings includes the power to consider claims of ineffective assistance of counsel based on conduct of counsel that occurred after the BIA entered a final order of removal. Holder resolved this issue by granting the Board this discretion.").

21824 I. \& N. Dec. 687 (A.G. 2008).

${ }^{219}$ Moncrieffe v. Holder, 569 U.S. 184, 190 (2013) (quoting Gonzales v. Duenas-Alvarez, 549 U.S. 183, 186 (2007) (citation omitted)).

220 See Mathis v. United States, 136 S. Ct. 2243, 2248 (2016) ("The comparison of elements that the categorical approach requires is straight-forward when a statute sets out a single (or 'indivisible') set of elements to define a single crime. The court then lines up that crime's elements alongside those of the generic offense and see if they match."). 
formed the basis of the defendant's prior conviction." 221 Once the offense of conviction has been established, the adjudicator then applies the categorial approach to that specific offense. ${ }^{222}$ Attorney General Mukasey concluded that the INA did not compel the same limitations in immigration proceedings, and instituted a third-step in the inquiry permitting immigration judges to "consider evidence beyond ... [the record of conviction] if doing so is necessary and appropriate to ensure proper application of the [INA's] moral turpitude provisions." 223 Despite a push from immigration advocates both for reconsideration by Mukasey and vacatur by Holder, ${ }^{224}$ the decision survived and was vigorously defended in the courts of appeals by the Department of Justice, perhaps owing to the noxious facts which involved the repeated molestation of a young girl by a 64-year old man. ${ }^{225}$

That vigorous defense faltered on a succession of adverse decisions in the courts of appeals, which rejected recourse to documents outside the scope originally contemplated by the categorical approach. ${ }^{226}$ Subsequent Supreme Court decisions clarifying application of the categorical and modified categorical approaches also undermined the logic of the Attorney General's decision, while placing into doubt the permissibility — even in the immigration context—of moving beyond the record of conviction as traditionally defined. ${ }^{227}$ These developments ultimately led to the vacatur of the decision by Attorney General Holder: "In view of the decisions of five courts of appeals rejecting the framework set out in Attorney General Mukasey's opinion-which have created disagreement among the circuits and disuniformity in the Board's application of immigration law - as well as intervening Supreme Court decisions that cast doubt on the continued validity of the opinion, I conclude that it is appropriate to vacate [that] opinion in its entirety."228

A different wrinkle on the categorical approach was presented in Matter of Chairez. Following the Supreme Court's decision in Descamps, disagreement arose over when a statute could be treated as divisible and thus amenable to analysis under the modified categorical approach. Some courts believed that textual analysis alone was relevant, and thus that a statute was divisible if phrased as presenting alternative elements, even if those distinct "elements" of the

\footnotetext{
${ }^{221}$ Descamps v. United States, 570 U.S. 254, 257 (2013).

222 See Mathis, 136 S. Ct. at 2249 (after applying the modified categorical approach, "[t]he court can then compare that crime, as the categorical approach commands, with the relevant generic offense.").

${ }^{223}$ Matter of Silva-Trevino, 24 I. \& N. Dec. at 699.

${ }^{224}$ See, e.g., Memorandum of Law of Am. Immigration Lawyers Assoc., et al., as Amici Curiae in Support of Reconsideration, Matter of Silva-Trevino, 24 I. \& N. Dec. 687 (A.G. 2008) (No. 013-014-303), http://immigrantdefenseproject.org/wp-content/uploads/2011/03/Silva-Trevino-Amicus.pdf.

${ }^{225}$ See, e.g., Mary Holper, The New Moral Turpitude Test: Failing Chevron Step Zero, 76 BROOK L. Rev. 1241, 1303 (2011) (decision could be seen "as a triumph of common sense (deport the child molester when a judge knows those were the facts) over creative lawyering (because the record of conviction does not show those facts, the child molester avoids deportation)."); Michael S. Vastine, From Bristol, to Hollywood, to a Land Far, Far Away: Considering the Immigration Consequences of Statutory Rape, 7 RUTGERS J.L. \& PUB. POL'Y 289, 318 (2010) (noting that SilvaTrevino involved "highly unfavorable facts involving a molestation of a child by a sixty-four year old man."). ${ }^{226}$ See Silva-Trevino v. Holder, 742 F.3d 197, 199-203 (5th Cir. 2014); see also Olivas-Motta v. Holder, 746 F.3d 907, 909-16 (9th Cir. 2013); Prudencio v. Holder, 669 F.3d 472, 480-82 (4th Cir. 2012); Fajardo v. U.S. Attorney Gen., 659 F.3d 1303, 1307-10 (11th Cir. 2011); Jean-Louis v. Attorney Gen., 582 F.3d 462, 473 (3d Cir. 2009); but see Mata-Guerrero v. Holder, 627 F.3d 256, 260-61 (7th Cir. 2010) (accepting permissibility of the third-step); Bobadilla v. Holder, 679 F.3d 1052, 1056-57 (8th Cir. 2012) (similar).

${ }^{227}$ See Moncrieffe v. Holder, 569 U.S. 184 (2013); see also Kawashima v. Holder, 132 S. Ct. 1166, 1172 (2012); Carachuri-Rosendo v. Holder, 560 U.S. 563, 581-82 (2010).

${ }^{228}$ Matter of Silva-Trevino, 26 I. \& N. Dec. 550, 553 (A.G. 2015).
} 
offense may not have been elements in the formal sense in which that term was often used. ${ }^{229}$ Other courts held that textual analysis was insufficient, since the alternative statutory phrases could be distinct means of committing a single offense rather than a recitation of distinct offenses each with its own set of elements. ${ }^{230}$ To ascertain whether the statute actually embodied distinct offenses, and was thus divisible, these courts would look to state law to determine whether jury unanimity was required regarding the statutory "element"; if so, the element was an element in the true sense of the term and the statute was divisible, but if not, the ostensible element was a means by which a single offense could be committed, and thus indicated an indivisible statute. ${ }^{231}$

The Board waded into this thicket in Matter of Chairez, holding that for a statute to be divisible, i.e., to encompass distinct offenses as opposed to different means to commit a single offense, jury unanimity was required regarding the statutory elements. ${ }^{232}$ Attorney General Lynch referred the case to herself for review, and directed briefing on "the proper approach for determining 'divisibility' within the meaning of Descamps v. United States, 133 S. Ct. 2276 (2013). In particular, does Descamps require that a criminal statute be treated as 'divisible' for purposes of the modified categorical approach only if, under applicable law, jurors must be unanimous as the version of the offense committed?"233 Shortly after, however, the Supreme Court itself resolved the issue, holding in Mathis that distinct elements are required in order to conclude that a statute is divisible, and that mere alternative means of committing a single offense is insufficient. ${ }^{234}$ In light of that decision, the Attorney General lifted the stay of proceedings and remanded for further action by the Board in light of Mathis. ${ }^{235}$

Finally, Matter of Dorman arose in the context of the Obama Administration's developing approach to litigation under the Defense of Marriage Act. ${ }^{236}$ The Administration ultimately came to the conclusion that DOMA was not constitutional and that it would not be defended in the federal courts, but that it would nonetheless still be applied in appropriate circumstances. ${ }^{237}$ The "application" part of the equation was at issue in Dorman, where the alien was denied cancellation of removal because he lacked a qualifying relative for purposes of establishing "exceptional and extremely unusual hardship" should he be removed, despite being in a legal same-sex civil union under New Jersey state law. ${ }^{238}$ Attorney General Holder referred and vacated the Board's decision, but declined to resolve any question presented on his own. ${ }^{239}$ Instead, he remanded proceedings to the Board for it to consider several questions he posed, including: 1) whether Dorman qualified as a "spouse" under New Jersey Law; 2) whether, in the absence of DOMA, he would qualify as a spouse under the INA; and 3) whether, if he did have a qualifying relative, he would be able to

\footnotetext{
${ }^{229}$ See, e.g., United States v. Trent, 767 F.3d 1046, 1061-61 (10th Cir. 2014).

${ }^{230}$ See, e.g., Rendon v. Holder, 764 F.3d 1077, 1086 (9th Cir. 2014).

${ }^{231}$ See id. (noting that the term "element" refers to "those circumstances on which the jury must unanimously agree").

23226 I. \& N. Dec. 349, 354 (BIA 2014) ("If Utah does not require such jury unanimity, then it follows that intent, knowledge, and recklessness are merely alternative 'means' by which a defendant can discharge a firearm, not alternative 'elements' of the discharge offense.").

${ }^{233}$ Matter of Chairez, 26 I. \& N. Dec. 686 (A.G. 2015).

${ }^{234}$ See Mathis, 136 S. Ct. at 2251-54, 2256-57.

${ }^{235}$ Matter of Chairez, 26 I. \& N. Dec. 796 (A.G. 2016).

23625 I. \& N. Dec. 485 (A.G. 2011).

${ }^{237}$ See United States v. Windsor, 570 U.S. 744, 753-54 (2013).

${ }^{238}$ See Joseph Landau, DOMA and Presidential Direction: Interpreting and Enforcing Federal Law, 81 FORDHAM L. REV. 619, 639 (2012).

${ }^{239}$ Matter of Dorman, 25 I. \& N. Dec. at 485.
} 
fulfill the "exceptional and extremely unusual hardship" standard for cancellation of removal. ${ }^{240}$ Dorman was subsequently married under New York law and obtained administrative closure of his removal proceedings. ${ }^{241}$ Despite not technically resolving an issue of substance, the decision did send a signal regarding how to approach same-sex issues raised in removal proceedings.

Again, unlike the Clinton Administration, the Obama Administration's failure to utilize the referral authority was not the product of pushing massive legislative reform, which arguably occupied the immigration-policy space that could have otherwise been devoted to referral. Instead, the Obama Administration focused on administrative programs implemented through policy memoranda - the Deferred Action for Childhood Arrivals program, instituted in June $2012,{ }^{242}$ the Deferred Action for Parents of Americans, instituted in November 2014, ${ }^{243}$ and other prosecutorial discretion-related initiatives. ${ }^{244}$ Even this focus obscures more than it reveals; it was nearly four years into the administration before DACA was instituted, and in that time the referral authority had not been used for any substantive decision. Leaving aside the point that these initiatives could not have totally occupied the space the administration could have devoted to immigration policy, they were on their face non-permanent programs subject to the vagaries of politics-rescission by an incoming administration. DAPA was enjoined and ultimately rescinded by the Trump Administration, while DACA, too, was rescinded with litigation based on the rescission reaching the Supreme Court. ${ }^{245}$ The program lives on at the moment, but further litigation seems likely if not certain.

In other words, the Obama Administration trafficked in internal policy initiatives that were peculiarly subject to who occupied the Executive Branch, while ignoring adjudicatory resolutions to other issues that would have had a better chance of more permanently changing the immigrationlaw landscape. It is of course true that adjudications are subject to challenge before the federal courts, and thus could have been abrogated there, similar to the litigation against both the DACA and DAPA programs. And it is also true that an Attorney General opinion may be vacated by a successor, as Attorney General Holder had done in Matter of Compean soon after taking office. The latter concern has not been a substantial feature of the referral authority during its history, and certainly not in circumstances were there have been no intervening changes in law or federal court interpretation that would upset the prior interpretation. And the former also seems less compelling; any review of the Attorney General's decision would be under the deference framework of Chevron, meaning even if challenged the courts should uphold the decision so long as it is a reasonable and permissible construction of the statute.

And, as with the Clinton Administration, the focus on DACA and DAPA did not exhaust the immigration policy possibilities. For instance, the administration challenged liberal constructions of the INA by the United States Court of Appeals for the Ninth Circuit all the way to the Supreme Court. In Matter of Escobar, the Board had held that a child had to meet the eligibility criteria for cancellation of removal on their own, and could not impute the parent's

\footnotetext{
240 Ibid.

${ }^{241}$ See Landau, supra note 238 , at 640 \& n.92.

242 See supra note 1.

${ }^{243}$ See supra note 2.

${ }^{244}$ See supra note 3. 
period of lawful permanent residence to themselves for purposes of meeting those criteria. ${ }^{246}$ The Ninth Circuit had rejected this rule, opining that in "allowing imputation, we merely implement the countervailing and coequal congressional policy of recognizing that present in the United States of an extended length gives rise to such strong ties to the United States that removal would result in undue hardship."247 Ultimately, the government prevailed before the Supreme Court, which held that the Board's interpretation was reasonable and permissible. ${ }^{248}$ The issue in Scialabba v. Cuellar de Osorio was more esoteric, and involved the question of when a child who reaches the age of majority before a visa is available to him may retain his priority date and convert his visa petition to another qualifying category. The Board had resolved the issue with a strict interpretation that provided relief to a limited class of aliens. ${ }^{249}$ The Ninth Circuit rejected that interpretation, ${ }^{250}$ but again the Supreme Court reversed, finding the agency decision a reasonable and permissible construction of ambiguous statutory language. ${ }^{251}$ The Board decisions the government defended in these cases were reasonable, but that is not the point; they were not the only possible interpretations of the statutory language, as the Supreme Court noted, ${ }^{252}$ and were in fact among the most restrictive possible readings of the statute. ${ }^{253}$ It is not difficult to imagine Attorney General Kennedy reaching out and resolving these cases differently through use of the referral authority.

And there were, of course, additional adjudicatory issues that could have been resolved, and resolved consistent with the administration's desire to implement a more humane immigration policy. The question of when and how private persecution could give rise to a colorable basis for asylum was still open in many contexts important to advocates-domestic-violence, gang-based claims, and construing family as a social group, for instance. The discrete components of the particular-social-group analysis could have benefited from Attorney General interpretation. ${ }^{254}$ Application of the post-departure bar to reopening proceedings had resulted in a conflict in the circuits that would have been amendable to Attorney General resolution. ${ }^{255}$ There would have been no shortage of issues on which to expend energies had the administration so desired, even before its later-stage myopic focus on DACA and related initiatives.

\footnotetext{
246 See Matter of Escobar, 24 I. \& N. Dec. 231 (BIA 2007).

${ }^{247}$ Cuevas-Caspar v. Gonzales, 430 F.3d 1013, 1029 (9th Cir. 2005).

${ }^{248}$ See Holder v. Martinez-Gutierrez, 566 U.S. 583, 598 (2011).

249 See Matter of Wang, 25 I. \& N. Dec. 28 (BIA 2009).

${ }^{250}$ See Cuellar de Osorio v. Mayorkas, 695 F.3d 1003 (9th Cir. 2012) (en banc).

${ }^{251}$ See Scialabba v. Cuellar de Osorio, 573 S. Ct. 41 (2014).

${ }^{252}$ See Cuellar de Osorio, 573 U.S. at 75 ("This is the kind of case Chevron was built for. Whatever Congress might have meant ... it failed to speak clearly. Confronted with a self-contradictory, ambiguous provision in a complex statutory scheme, the Board chose a textually reasonable construction consonant with its view of the purposes and policies underlying immigration law."); Martinez-Gutierrez, 566 U.S. at 592 ("Taken alone, the language of $\S$ $1229 \mathrm{~b}$ (a) at least permits the Board to go the other way - to say that 'the alien' must meet the statutory conditions independently, without relying on a parent's history.").

${ }^{253}$ Cuellar de Osorio, 573 U.S. at 73 (rejecting argument that "the BIA acted unreasonably in choosing the more restrictive reading").

254 See Elizabeth A. Rossi, A “Special Track” for Former Child Soldiers: Enacting a "Child Solider Visa” as an Alternative to Asylum Protection, 31 BERKELEY J. INT'L L. 392, 436 (2013) (raising referral in the context of clarifying the "social visibility" prong of the particular-social-group analysis).

${ }^{255}$ See Rachel E. Rosenbloom, Remedies for the Wrongly Deported: Territoriality, Finality, and the Significance of Departure, 33 U. HAW. L. REV. 139, 177 (2010).
} 


\section{REFERRAL IN A BIDEN ADMINISTRATION}

Immigration issues have been at the forefront of national debate for at least the last three administrations, with little reason to believe they will recede in importance during the current administration. The Biden Administration will have at its disposal all the traditional Executive Branch tools for advancing its agenda, including Executive Orders, internal memoranda, and rulemaking. Even in the midst of all these possibilities, it should not lose sight of the possibilities of referral. This concluding Part argues that there are many issues that would benefit from use of the referral authority, notwithstanding other avenues through which the administration can and should press its agenda. Thus, Subpart A begins by noting why referral may be peculiarly capable of resolving certain issues, while flagging potential areas that could be the focus of the authority. Subpart B turns to procedural issues, advancing potential reforms of the authority that could make it more effective.

\section{A. The Why and What of Referral}

The referral authority is unquestionably broad and could touch any interpretive issue under the INA and its implementing regulations. But that does not exhaust the range of issues the Biden Administration may want to address, and in fact its priorities may be better addressed through other Executive Branch and legislative mechanisms. This was true in the Obama Administration, where prosecutorial discretion and programmatic initiatives were prioritized. Referral took a backseat because it was not capable of effectuating the kind of policy options the administration was most concerned with.

Rather than ignoring referral, however, the Biden Administration can use it to bolster its policy agenda in areas where more substantial reform-legislative, regulatory, and programmatic - is not strictly necessary. This is the "why" of referral for the new administrationbecause the INA and its regulations contain many provisions which are ambiguous and which may lie outside the scope of future reforms, the Attorney General should exercise his authority to issue a controlling interpretation of the law to guide agency adjudicators. This possibility is compelling regardless of what broader reforms the administration might undertake. For instance, the possibility of issuing liberalizing constructions of relief provisions is important whether or not DACA remains in existence. So, too, similar constructions of inadmissibility and deportability provisions, including addressing the scope of the criminal grounds of removability. And in some ways, the benefits of referral are heightened in a context where the administration is able to secure either or both legislative and regulatory reforms. It would have the benefit of not only promulgating provisions sketching the contours of the reformed immigration system, but also maintaining the final interpretive authority over the new provisions, to the extent they are ambiguous, via the Attorney General's referral authority. There is thus no reason to believe that referral could not be a valuable component of the incoming administration's immigration policy agenda, regardless of what else it might be hoping to accomplish in this area.

Examples of the contexts in which referral could prove valuable illustrate this point. First, the Attorney General could elect to review categories of cases that touch on authorities that Congress has specifically given to him - the ability to grant (or deny) relief in the exercise of discretion, regardless of whether other eligibility criteria have been met. Asylum, for instance, 
may be denied to an alien who otherwise establishes statutory eligibility for relief, because that relief is ultimately discretionary. ${ }^{256}$ The same is true for cancellation of removal for both lawfulpermanent-residents and non-permanent residents, ${ }^{257}$ adjustment of status, ${ }^{258}$ and a variety of other waivers and forms of relief from removal. ${ }^{259}$ What would be at issue in any case that turns on a discretionary determination would be authority specifically given to the Attorney General by Congress to exercise his judgment in determining whether relief should be granted. An incoming Attorney General could address the question of discretion through the referral process, making clear to his delegates at the Board and in the immigration courts how that discretion should be exercised in close cases that present aliens who are statutorily eligible for relief but who nonetheless have negative equities that will factor into the question of whether relief should be granted. Or the Attorney General could act more broadly still, and direct referral in any case in which relief was granted or denied based on an ultimate exercise of discretion. This would allow the Attorney General to act as the final adjudicator in all cases touching on discretion, ensuring that where statutory eligibility has been met, any grant or denial of relief that would turn on judgment is made by the actor to whom Congress has directly delegated the responsibility of exercising that judgment.

Second, even confined to recent cases where a dissent has been registered by a Board member, there would be a wide range of substantive issues amenable to resolution through referral. In Matter of J.M. Acosta, the Board split 2-1 on whether IIRIRA's enactment of a new definition of "conviction" requires that the alien exhaust direct appeals before the conviction may be considered for immigration purposes. ${ }^{260}$ The majority, finding the statute ambiguous, held that the "long-standing requirement that a conviction must attain sufficient finality before immigration consequences attach ... survived the enactment of the IIRIRA."261 The dissent, in contrast, found the plain language of the statute conclusive in resolving the question, and because the INA's definition is met regardless of the pendency of direct review of the conviction, would have held that IIRIRA's definition does not require finality before immigration consequences may be imposed. ${ }^{262}$ Beyond the disagreement this question has engendered at the Board, in Matter of J.M.

\footnotetext{
${ }^{256}$ See 8 U.S.C. $\S 1158($ b)(1)(A) ("The Secretary of Homeland Security or the Attorney General may grant asylum to an alien who has applied for asylum in accordance with the requirements and procedures established ... under this section ..."').

${ }^{257}$ See 8 U.S.C. $§ 1229 b(a)$ ("The Attorney General may cancel removal in the case of" a lawful permanent resident" who is inadmissible or deportable from the United States" if the alien meets certain eligibility criteria); id. at $\S$ 1229 b(b) ("The Attorney General may cancel removal of, and just to the status of an alien lawfully admitted for permanent residence, an alien who is inadmissible or deportable from the United States," if the alien meets certain eligibility criteria).

${ }^{258}$ See 8 U.S.C. $\$ 1255$ (a) (the status of an alien "may be adjusted by the Attorney General, in his discretion and under such regulations as he may prescribe, to that of an alien lawfully admitted for permanent residence ...").

${ }^{259}$ See, e.g., 8 U.S.C. $§ 1182$ (h) (providing for the discretionary waiver of certain criminal grounds of inadmissibility); $i d$. at $\$ 1182(\mathrm{i})$ (providing for a discretionary waiver for an alien inadmissible for fraud or willful misrepresentation of a material fact).

26027 I. \& N. Dec. 420 (BIA 2018); see 8 U.S.C. $\$ 1101(\mathrm{a})(48)(A)$ (“The term 'conviction' means, with respect to an alien, a formal judgment of guilt of the alien entered by a court or, if adjudication of guilt has been withheld, where(i) a judge or jury has found the alien guilty or the alien has entered a plea of guilty or nolo contendere or has admitted sufficient facts to warrant a finding of guilty, and (ii) the judge has ordered some form of punishment, penalty, or restraint on the alien's liberty to be imposed.").

${ }^{261}$ Matter of J.M. Acosta, 27 I. \& N. Dec. at 431.

${ }^{262}$ Id. at 440 (Malphrus, Board Member, concurring in part, dissenting in part).
} 
Acosta and other cases, ${ }^{263}$ the courts of appeals have also issued conflicting decisions; some have concluded or hinted the finality requirement survived enactment of the IIRIRA, ${ }^{264}$ while the majority has leaned towards the conclusion that finality is no longer a requirement. ${ }^{265}$ The plain language of the statute may foreclose a more liberal construction, although the Board majority in Matter of J.M. Acosta did base its interpretation on a finding of ambiguity and compelling policy reasons for maintaining finality as a requirement for a conviction. ${ }^{266}$ In any event, given this range of disagreement in the agency and courts of appeals, Attorney General referral would provide an opportunity to consider the divergent views and resolve the question, at least for purposes of agency adjudications.

The Board has also issued companion decisions on application of the "material support" provision of the INA, which renders an alien inadmissible and ineligible for a range of discretionary relief and protection based on "engage[ment] in terrorist activity."267 The INA defines "engage in terrorist activity" to include "commi[ssion of] an act that the actor knows, or reasonably should know, affords material support, including a safe house, transportation, communications, funds, transfer of funds or other material financial benefit, false documentation or identification, weapons (including chemical, biological, or radiological weapons), explosives, or training," for certain designated terrorism-related reasons. ${ }^{268}$ The Board has concluded that this provision contains no exception for "material support" provided under duress, ${ }^{269}$ a decision that has been upheld by the courts of appeals as a permissible interpretation of the statute. ${ }^{270}$ It has also recently concluded, over a dissent, that there is no quantitative threshold for when support becomes material, and that all "material support" falls within the scope of this provision even if in some sense de minimis. ${ }^{271}$ In contrast, the dissent would have interpreted "material" to qualify support, by imposing a more-than-incidental or de minimis requirement on support before it would constitute "material support." 272 As with the duress-exception holding, the courts of appeals have deferred to the Board's conclusion. ${ }^{273}$ The uniform view of the courts of appeals may make this issue a poor one for Attorney General resolution, upsetting what would be consensus. At the same time, the obligation to establish controlling interpretations of the law rests with the Attorney

\footnotetext{
263 See Matter of Cardenas-Abreu, 24 I. \& N. Dec. 795 (BIA 2009) (en banc).

264 See Orabi v. U.S. Att'y Gen., 738 F.3d 535, 540-41 (3d Cir. 2014); see also United States v. Garcia-Echaverria, 374 F.3d 440, 445 (6th Cir. 2004); cf. Walcott v. Chertoff, 517 F.3d 149, 154 (2d Cir. 2008).

265 See Planes v. Holder, 652 F.3d 991, 996-97 (9th Cir. 2011); Puello v. Bureau of Citizenship \& Immigration Services, 511 F.3d 324, 332 (2d Cir. 2007); United States v. Sanez-Gomez, 472 F.3d 791, 793-94 (10th Cir. 2007); Montenegro v. Ashcroft, 355 F.3d 1035, 1037 (7th Cir. 2004) (per curiam); Moosa v. INS, 171 F.3d 994,1009 (5th Cir. 1999); see also Griffith v. INS, 243 F.3d 45, 49-51 (1st Cir. 2001).

${ }^{266}$ See Matter of J.M. Acosta, 27 I. \& N. Dec. at 424-29.

${ }^{267}$ See generally 8 U.S.C. $1182(\mathrm{a})(3)(\mathrm{B})$.

2688 U.S.C. $1182(\mathrm{a})(3)(\mathrm{B})(\mathrm{iv})(\mathrm{VI})$.

269 See Matter of M-H-Z-, 26 I. \& N. Dec. 757 (BIA 2016).

${ }^{270}$ See, e.g., Hernandez v. Sessions, 884 F.3d 107, 109 (2d Cir. 2018); Annachamy v. Holder, 733 F.3d 254 , 267 (9th Cir. 2013); Alturo v. U.S. Att'y Gen., 716 F.3d 1310 (11th Cir. 2013).

${ }^{271}$ Matter of A-C-M-, 27 I. \& N. Dec. 303, 307-11 (BIA 2018).

272 See id. at 313-15 (Wendtland, Board Member, dissenting).

${ }^{273}$ See, e.g., Hincapie-Zapata v. U.S. Attorney General, -- F.3d - (11th Cir. 2020); Rayamajhi v. Whitaker, 912 F.3d 1241, 1244-45 (9th Cir. 2019); Hosseini v. Nielsen, 911 F.3d 366, 376-77 (6th Cir. 2018); see also Sesay v. Attorney Gen. of U.S., 787 F.3d 215, 221 (3d Cir. 2015) (upholding conclusion that "low-level" support constituted "material support”); Barahona v. Holder, 691 F.3d 349, 351, 356 (4th Cir. 2012) (similar); Singh-Kaur v. Ashcroft, 385 F.3d 293, 296-301 (3d Cir. 2004) (similar).
} 
General, and to the extent there is room for disagreement about the proper interpretation it would be him to resolve (should he so desire).

A divided Board was on the other side of circuit opinion in Matter of Castillo Angulo. ${ }^{274}$ In order to establish eligibility for cancellation of removal for lawful permanent residents, the applicant must establish, inter alia, that he or she "has resided in the United States continuously for 7 years after having been admitted in any status[.]"275 The Fifth and Ninth Circuits had held that an alien who is "waved through" at a port of entry has been "admitted in any status," regardless of whether they were lawfully entitled to be admitted at the time they entered the United States. ${ }^{276}$ The Board rejected this interpretation of the statute, holding that the alien must possess some lawful immigration status at the time they are waved in, in order to be "admitted in any status."277 A dissenting member would have adopted the rule of the Fifth and Ninth Circuits, and held that a "wave through" admission constitutes an admission "in any status," even if the alien lacked any lawful basis on which to be admitted at that moment. ${ }^{278}$ This issue, resolved on the basis of the majority's conclusion that the statute is ambiguous, would be amenable to resolution by the Attorney General via referral. ${ }^{279}$ Although not an issue of broad importance-limited, as it is, to a discrete provision of a distinct form of relief, and implicating an even smaller subset of cases where the initial admission would have been a "wave through" where the applicant lacked any lawful basis for admission-it would still provide an opportunity for a potentially liberal construction of the statute.

There would also be significant opportunities to clarify the law relating to criminal offenses. The agency is entitled to deference in interpreting ambiguous provisions in the aggravated felony definition, for instance, an area where the Attorney General could intervene and establish a permissible generic definition of an otherwise undefined offense. ${ }^{280}$ The Board has recently interpreted several criminal provisions in decisions that provoked dissents, including the scope of the term "prostitution" in the aggravated felony provision, ${ }^{281}$ what constitutes an offense of stalking under the deportability provision, ${ }^{282}$ and the elements of the "receipt of stolen property offense" under the aggravated felony provision. ${ }^{283}$ Other ambiguous terms that have engendered

\footnotetext{
27427 I. \& N. Dec. 194 (BIA 2018).

2758 U.S.C. $\S 1229$ b(a)(2).

276 See Saldivar v. Sessions, 877 F.3d 812 (9th Cir. 2017); Tula-Rubio v. Lynch, 787 F.3d 288 (5th Cir. 2015).

277 See Matter of Castillo Angulo, 27 I. \& N. Dec. at 196-202.

${ }^{278} \mathrm{Id}$. at 204-06 (Pauley, Board Member, concurring in part, dissenting in part).

${ }^{279} \mathrm{Id}$. at 196-97 (noting ambiguity of the statute).

${ }^{280}$ See Soto-Hernandez v. Holder, 729 F.3d 1, 4 (1st Cir. 2013); Mugalli v. Ashcroft, 258 F.3d 52, 56 (2d Cir. 2001); Restrepo v. Attorney General, 617 F.3d 787, 795-96 (3d Cir. 2010); Espinal-Andrades v. Holder, 777 F.3d 163 , 169 (4th Cir. 2015); Alwan v. Ashcroft, 388 F.3d 507, 513-15 (5th Cir. 2004); Velasco-Giron v. Holder, 773 F.3d 774, 776 (7th Cir. 2014); Spacek v. Holder, 688 F.3d 536, 538 (8th Cir. 2012); Renteria-Morales v. Mukasey, 551 F.3d 1076, 1081 (9th Cir. 2008); Balogun v. U.S. Att'y Gen., 425 F.3d 1356, 1361 (11th Cir. 2005).

${ }^{281}$ See Matter of Shuying Ding, 27 I. \& N. Dec. 295 (BIA 2018); see also 8 U.S.C. § 1101(a)(43)(K)(i) (aggravated felony defined to include "an offense that-relates to the owning, controlling, managing, or supervising of a prostitution business").

${ }^{282}$ See Matter of Sanchez-Lopez, 27 I. \& N. Dec. 256 (BIA 2018); see also 8 U.S.C. § 1227(a)(2)(E)(i) (“Any alien who at any time after admission is convicted of a crime of domestic violence, a crime of stalking, or a crime of child abuse, child neglect, or child abandonment is deportable.").

283 See Matter of Deang, 27 I. \& N. Dec. 57 (BIA 2017); see also 8 U.S.C. 1101(a)(43)(G) (aggravated felony defined to include "a theft offense (including receipt of stolen property) or burglary offense for which the term of imprisonment [is] at least one year").
} 
significant litigation include the "sexual abuse of a minor" provision of the aggravated felony definition, and the "crime of child abuse" ground of deportability, both of which could be clarified in scope and regarding specific applications. Clarification of general terminology would also be beneficial, as in what offenses qualify as an offense "relating to" specific categories of crime. ${ }^{284}$

The point here is not to exhaustively detail the issues that the Biden Administration could address if it so desired, but simply to sketch the possibilities. Assuming Kennedy as a guide, even this overview shows the potential of referral for an administration inclined to liberal interpretation. It could define eligibility criteria for relief liberally — concluding, for instance, that de minimis support under duress to a terrorist organization is not "material" and thus not disqualifying, or that a "wave through" admission is sufficient in gauging the seven years" presence required for cancellation of removal for lawful permanent residents. Of course, as already noted, some provisions might nonetheless require the stricter interpretation, as the definition of conviction seems to require. But even that is in line with the broad purpose of referral and is not inconsistent with an otherwise liberal inclination; as Kennedy's experience shows, the point is that the Attorney General must be guided by the law, but that where the law does admit of multiple reasonable interpretations it rests with him to alight upon the one he deems most in accord with the purpose and policy of the provision.

\section{B. Institutionalizing Referral}

To realize the potential of Attorney General referral, it should be institutionalized by the incoming administration. In the initial transfer of functions, the regulations did provide for a "Special Assistant in Charge" of immigration functions, ${ }^{285}$ and this position seems to have been filled at least at certain points in the past. ${ }^{286}$ The first regulation governing referral also contemplated the referral of a broader range of cases to the Attorney General, including all in which discretionary relief had been granted under former Section 19(c) of the INA, all in which a dissent had been recorded, and any in which the Board certified "a question of difficulty" was involved. ${ }^{287}$ A dedicated official coupled with a broader range of issues susceptible to essentially mandatory referral ensured a significance usage of the referral authority following the transfer of functions to the Department of Justice. ${ }^{288}$

\footnotetext{
${ }^{284}$ See 8 U.S.C. $\S 1101(a)(43)(Q)$ ("an offense relating to a failure to appear by a defendant for service of sentence if the underlying offense is punishable by imprisonment for a term of 5 years or more"); id. at $\S 1101(\mathrm{a})(43)(\mathrm{R})$ ("an offense relating to commercial bribery, counterfeiting, forgery, or trafficking in vehicles the identification numbers of which have been altered for which the term of imprisonments is at least one year"); id. at $\$ 1101(\mathrm{a})(43)(\mathrm{S})$ ("an offense relating to obstruction of justice, perjury or subornation of perjury, or bribery of a witness, for which the term of imprisonment is at least one year"); $i d$. at $\S 1101(\mathrm{a})(43)(\mathrm{T})$ ("an offense relating to a failure to appear before a court pursuant to a court order to answer to or dispose of a charge of a felony for which a sentence of 2 years' imprisonment or more may be imposed").

${ }^{285}$ See Delegation of Powers and Definition of Duties, 5 Fed. Reg. 2454, 2454 (July 1, 1940) (referring to the Special Assistant in Charge).

${ }^{286}$ See, e.g., Matter of C-, 1 I. \& N. Dec. 631, 633 n.2 (BIA 1943) (noting a memorandum from a "Special Assistant to the Attorney General").

${ }^{287}$ See 8 C.F.R. § $90.12(1940)$.

${ }^{288}$ See generally Gonzales \& Glen, supra note 4, at 857 (noting pace of decisions between 1940 and 1952, as well as the drop off in frequency beginning with the Eisenhower Administration).
} 
In order to make referral a central part of its immigration policy, the Biden Administration should return to the spirit of referral's early days. Broadening the scope of referral would be the likely first step. Through rule-making, the administration could implement changes to the cases for which referral would be required. As noted above, the administration could direct referral in all cases where the agency decided the ultimate question of relief based on an exercise of discretion, a rule that would harken back to the initial referral regulation. It could also, in light of the cases where disagreement on interpretive issues has divided the Board, mandate referral of any case in which a Board Member registers a dissent; again, an operating principle embodied in the initial rule. These changes would unquestionably increase the pace of referrals to the Attorney General, and would do so in situations where his statutorily granted authority is most at issuethose involving discretionary judgments regarding relief and those that require a definitive interpretation of potentially ambiguous statutory language. The balance of the existing regulation would remain, ensuring additional avenues of referral - through certification by the Chairman of the Board, relevant officials in the Department of Homeland Security, and by the Attorney General himself.

To ensure that the higher volume of cases is adequately dealt with upon referral, the Attorney General should appoint a dedicated Special Assistant to handle adjudicatory matters. This role is currently filled by the Office of Legal Counsel, and for that reason suffers - attorney advisors in OLC are generalists with little to no subject matter expertise on immigration matters. ${ }^{289}$ There is also little likelihood that an OLC attorney could fulfill a dedicated role to immigration matters of this kind, and no reason why the function should exist in OLC rather than in the Attorney General's Office itself.

The Special Assistant would be charged with review of referred matters in the first instance, including determining whether the matter actually merits intervention by the Attorney General; referral is, after all, a mechanism to bring a case to the attention of the Attorney General, but it does not require an adjudication of the underlying merits of the case. ${ }^{290}$ If a matter were accepted for review, the Special Assistant would be charged with functions similar to a judicial clerk'sreviewing incoming pleadings, consulting with the Attorney General about the disposition of the case, and drafting the opinion itself. In this fashion, the Attorney General could more fully fulfill the potential of referral, as there would be an individual whose portfolio focused exclusively on the referral and decision of cases. Moreover, with such a dedicated official, the manner of referral could also be expanded. The Attorney General could, for instance, implement a dedicated email address through which aliens could flag their cases for review. There is nothing inappropriate about requests that the Attorney General self-refer cases, ${ }^{291}$ and this could open up avenues

\footnotetext{
289 See, e.g., Cornelia Pillard, Unitariness and Myopia: The Executive Branch, Legal Process, and Torture, 81 IND. L.J. 1297, 1310 (2006) ("OLC is staffed with legal generalists, not individual-rights experts, and they typically lack particular familiarity with the institutional conditions that foster or, alternatively, help to prevent rights violations."). 290 See, e.g., Matter of C-Y-Z-, 23 I. \& N. Dec. 693 (A.G. 2004) (denying to review a case referred by the Commissioner of the INS); see also Zhang v. Slattery, 55 F.3d 732, 741 (2d Cir. 1995) (noting Attorney General Reno's decision declining to decide the merits of a case that had been referred to her for decision).

${ }^{291}$ See Matter of C-, 4 I. \& N. Dec. 130, 133 (A.G. 1950) (noting that "[t]he alien, through counsel, ... filed a petition with the Attorney General requesting the relief denied by the [INS] and by the Board of Immigration Appeals"); $c f$. Matter of Pierre, 14 I. \& N. Dec. 467, 471 (BIA 1973) (noting, but denying, a request by alien's counsel to refer the case to the Attorney General); Matter of Garcia-Castillo, 10 I. \& N. Dec. 790, 793 (BIA 1964) (same); Matter of E- 6 I. \& N. Dec. 388, 391 (BIA 1954) (same); see also Bah v. Mukasey, 529 F.3d 99, 110 n.14 (2d Cir. 2008) (noting
} 
whereby the Attorney General would be presented with additional opportunities to exercise discretion under the INA (for instance, in assessing hardship questions under various relief provisions).

\section{CONCLUSION}

Institutionalizing and mainstreaming referral may seem like an odd suggestion, coming after four years of concerted criticism from many who may well fill the ranks of the incoming administration. But it makes significantly more sense than the alternative-disclaiming any recourse to referral simply because of disagreement with the substantive decisions prior administration's have issued pursuant to the authority. That is especially true where the authority is a neutral mechanism for advancing immigration policy; it is not inherently "conservative" or "restrictionist," and can meet the goals of advancing a liberal immigration policy when wielded by an Attorney General who is so inclined. That is true objectively, but this article has also advanced a specific example of just such a use of the authority, that of former Attorney General Robert Kennedy. Kennedy's pragmatic and humane approach to the adjudication of immigration issues should serve as a model to the incoming administration. So conceived, the referral authority can be an important facet of the Biden Administration's immigration policy agenda.

requests from politicians and non-governmental organizations that the Attorney General refer a Board decision to himself for decision). 